\title{
Evaluation of torrefied poplar-biomass as a low-cost sorbent for lead and terbium removal from aqueous solutions and energy co-generation
}

\author{
H. Demey ${ }^{\mathrm{a}, *}$, T. Melkior ${ }^{\mathrm{a}}$, A. Chatroux ${ }^{\mathrm{a}}$, K. Attar ${ }^{\mathrm{b}}, \mathrm{S}$. Thiery ${ }^{\mathrm{a}}$, H. Miller ${ }^{\mathrm{a}}$, M. Grateau ${ }^{\mathrm{a}}$, A.M. Sastre ${ }^{\mathrm{b}}$, \\ M. Marchand ${ }^{\mathrm{a}}$ \\ ${ }^{a}$ Commissariat à l'Energie Atomique et aux Energies Alternatives, CEA/DRT/LITEN/DTBH/STHB/LPB, 17 rue des Martyrs, 38054 Grenoble, France \\ ${ }^{\mathrm{b}}$ Universitat Politècnica de Catalunya, Department of Chemical Engineering, ETSEIB, Diagonal 647, 08028 Barcelona, Spain
}

\section{A R T I C L E I N F O}

\section{Keywords:}

\section{Bioenergy}

Bio-resource

Higher heating value

Metal recovery

Valorization

Water treatment

\begin{abstract}
A B S T R A C T
Two low-cost renewable poplar-based materials were manufactured in this work for energy production and as sorbents for lead and terbium removal from aqueous effluents. Torrefaction was used as a pretreatment process for conditioning the raw biomass. Two different operating conditions were used in the multiple-hearth furnace of the torrefaction pilot-plant: i) $250^{\circ} \mathrm{C}$; ii) $280^{\circ} \mathrm{C}$, with residence times of $75 \mathrm{~min}$ and $60 \mathrm{~min}$, respectively. The raw and torrefied biomasses have been characterized using SEM-EDX, FTIR, TGA, XRD and elemental analyses (C, H, N, S, O); an increase of the torrefaction severity, results in an increase of the carbon/oxygen ratio and in a greater mass loss $\left(21 \%\right.$ at $250^{\circ} \mathrm{C}$, and $53 \%$ at $\left.280^{\circ} \mathrm{C}\right)$. The torrefaction had a positive impact on the sorption of metals, it allowed the increase of lignin content of the manufactured materials, and it allowed the storage of the sorbents for longer time with reduced moisture content. The equilibrium studies were performed in batch system and the experimental data were described with the Sips equation. The maximum sorption capacity was found as $30 \mathrm{mg} \mathrm{g}^{-1}$ for lead and $9.4 \mathrm{mg} \mathrm{g}^{-1}$ for terbium (at pH 4). The kinetic profiles were fitted using the pseudo-second order rate equation. The regeneration of the sorbent was demonstrated by three sorption-desorption cycles using dilute $\mathrm{HNO}_{3}$ solution $(0.1 \mathrm{M})$ as eluent for metal recovery.
\end{abstract}

\section{Introduction}

The research on renewable sources of energy has been the main scope of worldwide scientists during the last decade. The development of the economy is directly linked to the energy reserves of any country. However, the depletion of fossil-fuels and the increased environmental pollution have boosted the exploration of the green-energy alternatives, which are essentially associated to solar, wind, ocean, geothermal and biomass resources [1].

Currently, biomass covers approximately $10 \%$ of the global primary energy demand [2]; it is abundant and can be obtained from plants and animals without competing with the world food supplies. The agricultural wastes and the forestry residues represent the best way for energy generation, since the huge availability makes feasible the thermal conversion into solid, liquid and gaseous fuels.

Several pretreatment processes such as pyrolysis and torrefaction can be used for processing the biomass into useful products. Torrefac- tion is promising since the resulting materials have similar properties to coal, and these additionally, can be densified into pellets or briquettes to produce highly calorific materials $[3,4]$; the main advantage over pyrolysis is the low input of energy required into the system and the low loss of mass. Many authors have reported that torrefaction improves the physical characteristics of the feedstock: it contributes to increase the hydrophobicity and the brittleness [5,6], which reduces the energy requirement for grinding into smaller particles size for further gasification applications [7].

Torrefaction is characterized by the low range of operating temperatures (usually between $200^{\circ} \mathrm{C}$ and $300^{\circ} \mathrm{C}$ ) in an inert ambient. Wang et al. [8] reported that torrefied wood materials (at temperatures between 225 and $300^{\circ} \mathrm{C}$ ) have a higher content of lignin and a lower content of hemicellulose and cellulose than the original raw biomass, thus, the functional groups are still available in the polymer network (such as carboxylates and hydroxyls groups mainly). Due to these properties, the torrefaction of the forestry wastes is a suitable way for producing sorbents for metal removal from effluents. Therefore, the val-

\footnotetext{
* Corresponding author.

Email address: hary.demey@upc.edu, hary.demeycedeno@cea.fr (H. Demey)
} 

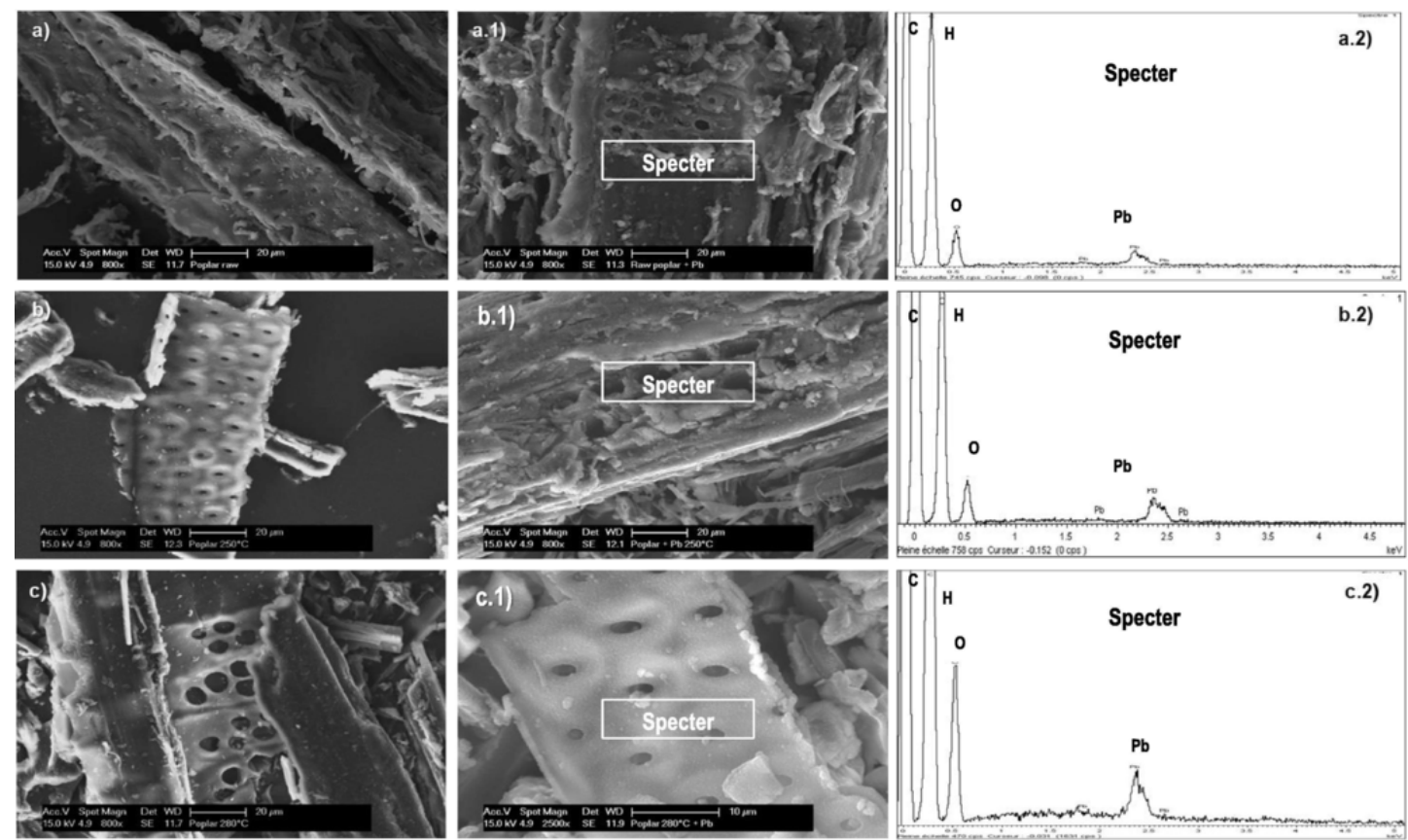

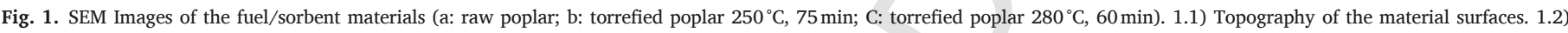
EDX-analyses on the material surfaces.
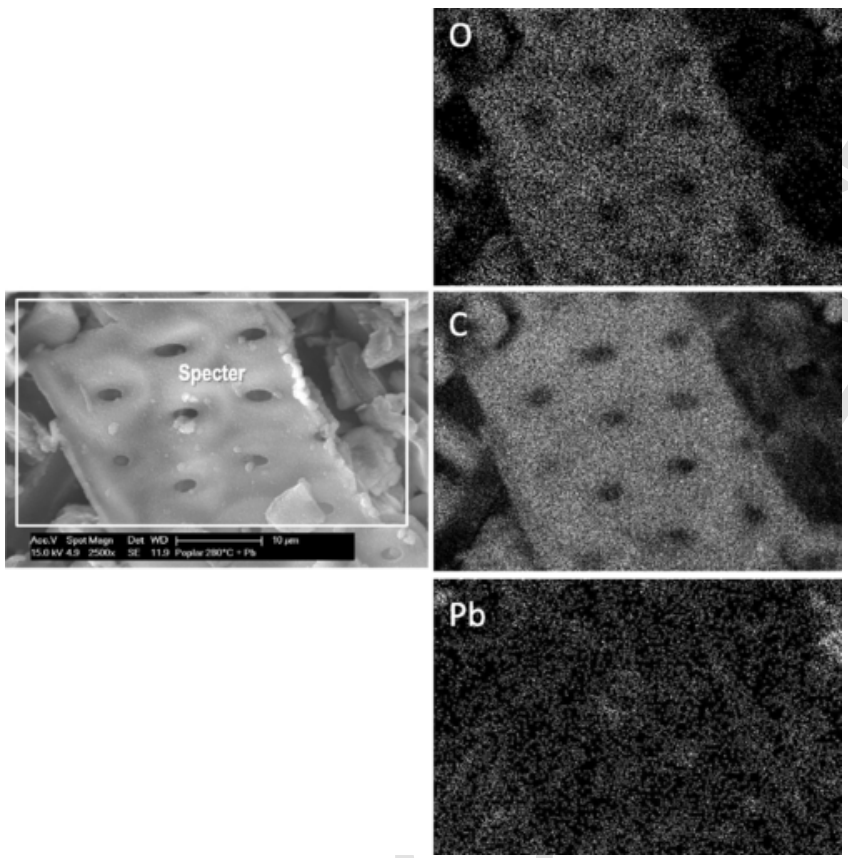

Fig. 2. Distribution of the main elements present on the surface of torrefied poplar biomass after metal sorption. (Right side: surface of raw poplar; left side: distribution of O: Oxygen, C: Carbon, Pb: lead).

orization of bio-resources via torrefaction can be performed for two objectives: i) metal uptake from waters; ii) energy generation.

Among the methods for effluents depollution, biosorption has many advantages for removing dilute metal ions face to flocculation-coagulation $[9,10]$ and solvent extraction $[11,12]$ techniques: the simplicity of the process and the easy availability of the sorbents, involve lower operation costs of the system. Moreover, the thermal pre-conditioning of the biomass is crucial for achieving high performances, since the presence of reactive groups is essential to achieve this goal [13].

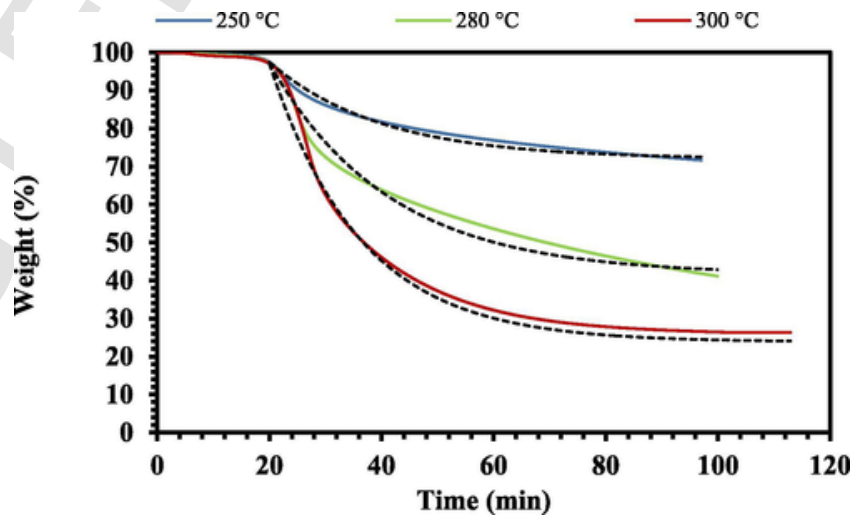

Fig. 3. Thermal decomposition kinetic of poplar-based biomass. (Dashed line: empirical model; $\mathrm{T}_{1}: 250^{\circ} \mathrm{C} ; \mathrm{T}_{2}: 280^{\circ} \mathrm{C} ; \mathrm{T}_{3}: 300^{\circ} \mathrm{C}$; sample mass: $5 \mathrm{mg}$; initial heating rate: $10^{\circ} \mathrm{Cmin}^{-1}$; nitrogen flow rate: $50 \mathrm{~mL} \mathrm{~min}^{-1}$ ).

Previous studies have reported the use of several technologies based on different types of biomasses for separating heavy metals from aqueous solutions; e.g., Demey et al. [14] provided a practical one-pot process for rapid manufacturing of sorbent using Fucus vesiculosus alga; the sorption capacities followed the order: $\mathrm{Cu}(\mathrm{II})>\mathrm{Pb}(\mathrm{II})>\mathrm{Zn}(\mathrm{II}) \approx \mathrm{Ni}(\mathrm{II})>\mathrm{Cd}(\mathrm{II})$. Edathil et al. [15] designed a novel magnetic nanocomposite from coffee waste as effective biosorbent for lead removal from waters: the maximum sorption capacity achieved was $41 \mathrm{mg} \mathrm{g}^{-1}$ and the results showed that oxygen rich surface plays an important role for enhancing the removal uptake. Similar conclusions were found by Demey et al. [13] and Lapo et al. [16], the introduction of iron(III) hydroxide into a chitosan matrix, improves the mechanical strength and the sorption performance of the sorbent.

Particular attention should be paid to rare earth elements (REEs). The literature for RREs recovery through biosorption process is still scarce (in comparison with heavy metals); e.g., terbium is a key element in the high-tech industries; its applications include the manufacturing of fluorescent lamps and fuel cells, the production of high strength permanent magnets, the fabrication of electrical motors in hy- 
Table 1

Composition and energy content of poplar-based biomass.

\begin{tabular}{|c|c|c|c|c|c|c|c|c|c|c|c|c|c|}
\hline \multicolumn{6}{|l|}{ Elemental analyses } & \multirow{2}{*}{$\begin{array}{l}\text { Ash content } \\
\left(550^{\circ} \mathrm{C}\right)\end{array}$} & \multicolumn{2}{|c|}{ Energy content } & \multicolumn{2}{|c|}{ Macromolecular composition } & \multicolumn{2}{|l|}{$\Delta$} & \multirow[b]{2}{*}{$\begin{array}{l}\text { Total } \\
\text { lignin } \\
(\%)\end{array}$} \\
\hline Material & $\mathrm{C}(\%)$ & $\begin{array}{l}\mathrm{H} \\
(\%)\end{array}$ & $\begin{array}{l}\mathrm{N} \\
(\%)\end{array}$ & $\begin{array}{l}\text { S } \\
(\%)\end{array}$ & $\begin{array}{l}\mathrm{O} \\
(\%)\end{array}$ & & $\begin{array}{l}\mathrm{HHV}^{*} \\
\left(\mathrm{MJ} \mathrm{kg}^{-1}\right)\end{array}$ & $\begin{array}{l}\mathrm{HHV}^{* * *} \\
\left(\mathrm{MJ} \mathrm{kg}^{-1}\right)\end{array}$ & $\begin{array}{l}\text { Hemicellulose } \\
(\%)\end{array}$ & $\begin{array}{l}\text { Cellulose } \\
(\%)\end{array}$ & $\begin{array}{l}\text { Klason } \\
\text { lignin } \\
(\%)\end{array}$ & $\begin{array}{l}\text { Soluble } \\
\text { lignin } \\
(\%)\end{array}$ & \\
\hline $\begin{array}{l}\text { Raw Poplar (Populus } \\
\text { sp.) }\end{array}$ & 46.65 & 5.60 & 0.26 & 0.03 & 44.66 & 2.80 & 18.60 & 18.42 & 21.75 & 42.72 & 24.50 & 2.41 & 26.91 \\
\hline $\begin{array}{r}\text { Torrefied Poplar } \\
250^{\circ} \mathrm{C}, 75 \mathrm{~min}\end{array}$ & 52.44 & 5.65 & 0.32 & 0.03 & 38.17 & 3.39 & 20.90 & 20.81 & 10.39 & 44.07 & 37.35 & 1.09 & 38.44 \\
\hline $\begin{array}{r}\text { Torrefied Poplar } \\
280^{\circ} \mathrm{C}, 60 \mathrm{~min}\end{array}$ & 60.10 & 5.70 & 0.39 & 0.03 & 29.50 & 4.28 & 23.90 & 24.36 & 3.59 & 23.93 & 68.06 & 0.52 & 68.58 \\
\hline
\end{tabular}

"HHV obtained from bomb calorimeter analysis; "*HHV obtained from Eq. (1).

Table 2

Kinetic parameters of the thermal conversion of poplar biomass.

\begin{tabular}{|c|c|c|c|c|c|c|c|}
\hline \multicolumn{2}{|c|}{ Experimental (TGA) } & \multicolumn{3}{|c|}{ Predicting model (PFORE) } & \multicolumn{3}{|c|}{ Torrefaction pilot-plant (CENTORRE) } \\
\hline Sorbent & $\mathrm{W}_{\exp }(\% \mathrm{w} / \mathrm{w})$ & $\mathrm{K}_{\mathrm{T}}\left(\min ^{-1}\right)$ & $\mathrm{W}_{\mathrm{p}}(\% \mathrm{w} / \mathrm{w})$ & $\mathrm{r}^{2}$ & Inlet flow rate $\left(\mathrm{kg} \mathrm{h}^{-1}\right)$ & Outlet flow rate $\left(\mathrm{kg} \mathrm{h}^{-1}\right)$ & $\mathrm{W}_{\text {pilot-plant }}(\% \mathrm{w} / \mathrm{w})$ \\
\hline $250^{\circ} \mathrm{C}$ & 24.72 & $4.66 \times 10^{-2}$ & 23.61 & 0.978 & 145.2 & 114.8 & 20.90 \\
\hline $280^{\circ} \mathrm{C}$ & 51.18 & $3.92 \times 10^{-2}$ & 51.17 & 0.973 & 121.3 & 57.1 & 52.93 \\
\hline $300^{\circ} \mathrm{C}$ & 64.36 & $6.79 \times 10^{-2}$ & 64.03 & 0.995 & - & - & - \\
\hline
\end{tabular}

$\Delta$ Raw poplar biomass aTorrefied poplar $250^{\circ} \mathrm{C}, 75 \mathrm{~min}$ OTorrefied Poplar $280^{\circ} \mathrm{C}, 60 \mathrm{~min}$

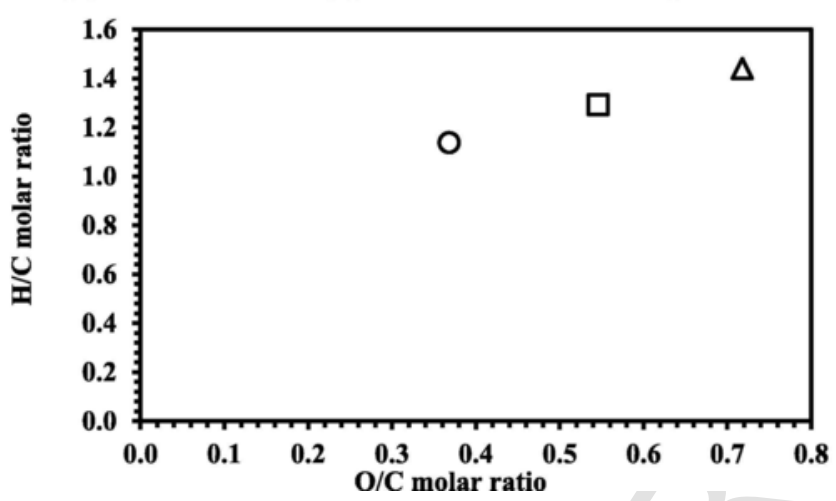

Fig. 4. Van Krevelen plot of poplar-based biomass.

brid vehicles and wind turbine generators [17]. The concentration of $\mathrm{Tb}$ (III) in the earth's crust is low $\left(0.7-2.5 \mathrm{mg} \mathrm{Kg}^{-1}\right)$, it is considered as a critical metal due to the possible shortage in the Chinese exportations toward EU and USA [18]. The US Department of Energy reported the need of further research for recycling this critical metal [18]. Therefore, the development of novel technologies for terbium recovery is an important task nowadays.

This study describes the thermal preparation of environmental-friendly materials using the torrefaction process for two goals: water treatment, and energy generation. By first time, poplar biomass has been used as a sorbent for terbium separation from waters. Terbium and lead species were chosen for sorption studies because are commonly present in the industrial effluents of the batteries and electronic devices recycling, and may coexist in metallurgical wastewaters. Typically, a sorbent used for metal removal, after reaching its service life (after enough cycles of sorption-desorption), must be treated and disposed as Hazardous Waste (HW) due to the existence of toxic metals in it. As the capital cost of treatment of HW is usually very high, it would be much useful for reducing the cost if the hazardous waste itself could produce higher calorific value in the final incineration process [19].

Poplar tree biomass (Populus, sp.) was selected due to the highly abundance and to the rapid adaptability of their derived species into different ecosystems and weather conditions; the main advantage of this forestry bio-resource is that the trunk grows up at large size in a short period of time $[20,21]$. In this work, the characterization results of the materials are presented (before and after torrefaction), as well as the sorption results in batch system; the ion selectivity was evaluated under equimolar binary solutions, and the regeneration of the sorbent was tested with dilute $\mathrm{HNO}_{3}$ solution $(0.1 \mathrm{M})$.

\section{Experimental methods}

\subsection{Materials}

The raw poplar biomass (chips of the Populus sp. trunk) was provided by RAGT Energie (Albi, France) in the frame of the European project MOBILE-FLIP; the samples were collected in France $\left(43^{\circ} 36^{\prime} \mathrm{N}, 1^{\circ} 26^{\prime} \mathrm{O}\right)$, and the initial moisture content was measured as $4.5 \% \mathrm{w} / \mathrm{w}$. The inorganic reagents, such as nitric acid and sodium hydroxide were provided by Prolabo (Barcelona, Spain). Terbium and lead solutions were prepared by using $\mathrm{TbCl}_{3} \cdot 6 \mathrm{H}_{2} \mathrm{O}$ (Alfa Aesar, Haverhill, Massachusetts, USA) and $\mathrm{Pb}\left(\mathrm{NO}_{3}\right)_{2}$ (purity 98\%, Panreac, Barcelona, Spain), respectively. Demineralized Milli-Q water was used for preparing the solutions of all experimental tests.

\subsection{Torrefaction process}

The preparation of the solid-fuel materials was carried out through torrefaction process using a vertical furnace with multiple hearths (the so-called CENTORRE oven: i.d. $\varnothing 1.82 \mathrm{~m}$, hearth height: $0.74 \mathrm{~m}$; including a rotatory axis, i.d. $\varnothing 0.42 \mathrm{~m}$ ) provided by $\mathrm{Cmi}$ Group technology (Seraing, Belgium). The column is equipped by six hearths or stages in which are present two burners by stage, achieving temperatures in the range of $200^{\circ} \mathrm{C}$ to $350^{\circ} \mathrm{C}$. An internal rabbling system is provided for enhancing the transport and the displacement of the biomass into the hearths.

Before feeding the furnace with the raw biomass, it was firstly heated overnight at the temperature chosen for operating torrefaction. The flow rate of biomass (Q) was set at $Q \geq 120 \mathrm{Kgh}^{-1}$ (during $20 \mathrm{~h}$ of operation time) for approaching to the real industrial production, and two torrefaction conditions were considered : i) $250^{\circ} \mathrm{C}$; ii) $280^{\circ} \mathrm{C}$ with residence times of $75 \mathrm{~min}$ and $60 \mathrm{~min}$, respectively. The torrefied bio- 
a) $\backsim$ Raw poplar biomass $\backsim$ Torrified poplar $250^{\circ} \mathrm{C} \_75 \mathrm{~min}$ औ Torrified poplar $280^{\circ} \mathrm{C} \_60 \mathrm{~min}$

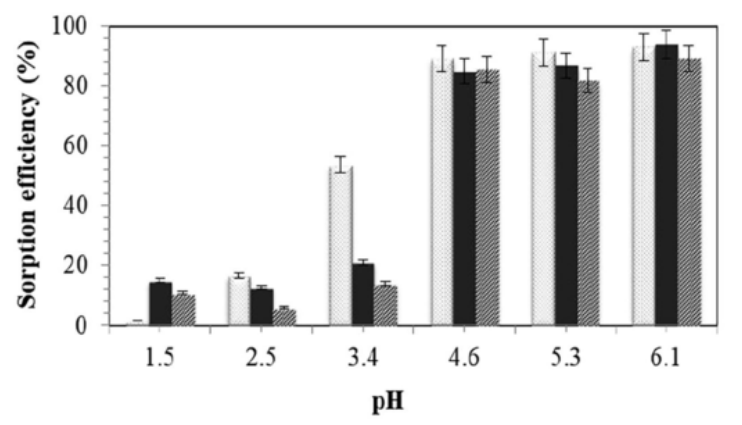

b)
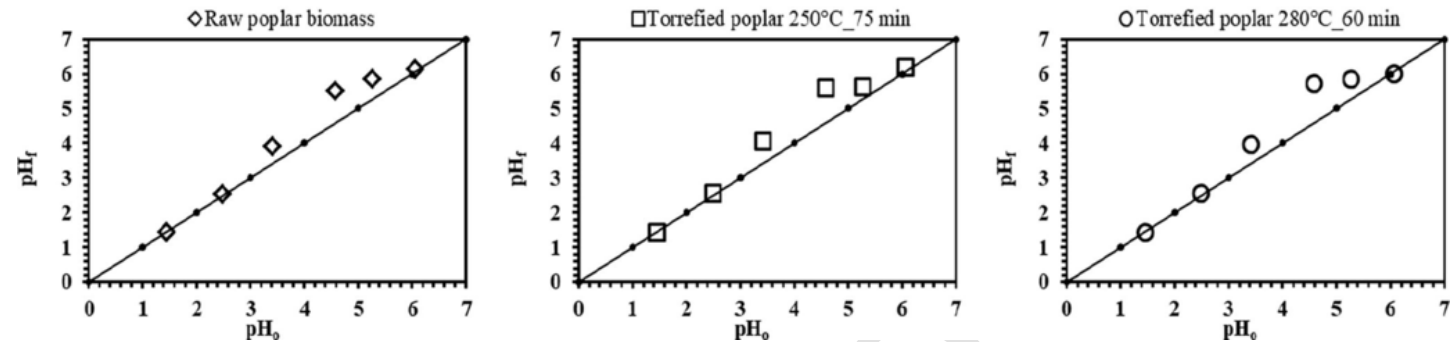

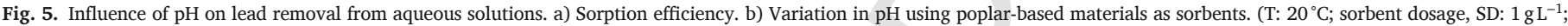
agitation speed: $150 \mathrm{rpm}$; contact time: $24 \mathrm{~h} ; \mathrm{C}_{0}: 10 \mathrm{mg} \mathrm{L}^{-1}$ ).

a) $\square$ Raw poplar biomass $\square$ Torrified poplar $250^{\circ} \mathrm{C} \_75 \mathrm{~min}$ : $\mathrm{T}$ orrified poplar $280^{\circ} \mathrm{C} \_60 \mathrm{~min}$

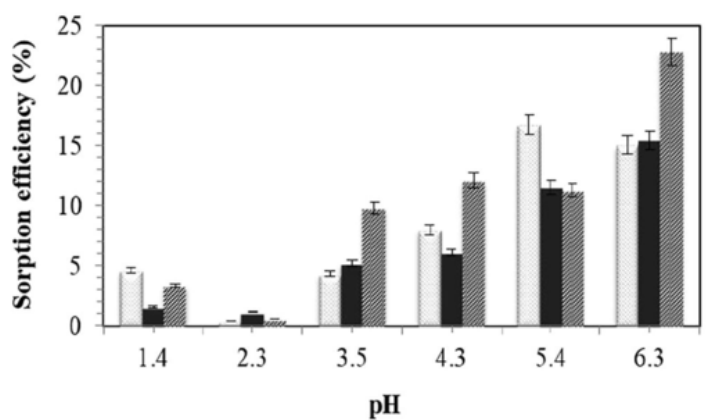

b)
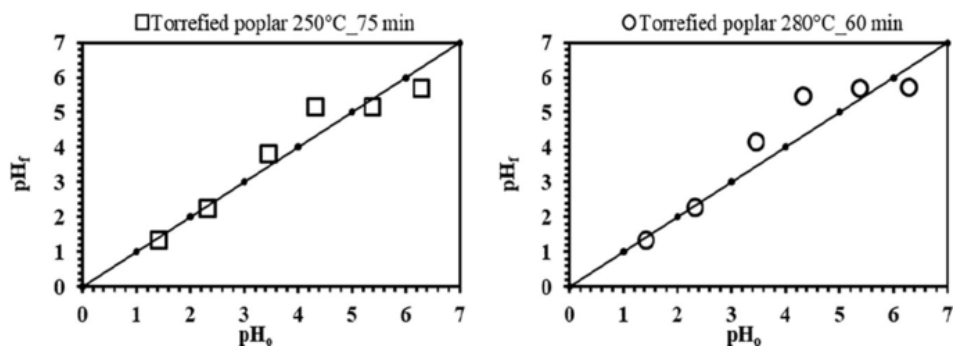

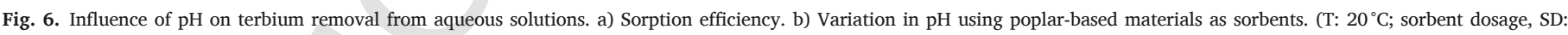
$1 \mathrm{gL}^{-1}$; agitation speed: $150 \mathrm{rpm}$; contact time: $24 \mathrm{~h} ; \mathrm{C}_{0}: 10 \mathrm{mg} \mathrm{L}^{-1}$ ).

mass exiting the oven was cooled down into two successive screw conveyors and finally collected in airtight containers of $1 \mathrm{~m}^{3}$ volume (in which it was additionally introduced nitrogen stream for maintaining low oxygen content, $<5 \%$ ). The mass and energy yields of the tests were then calculated, and the torrefied biomass was characterized.

\subsection{Characterization of sorbents}

The raw and torrefied biomasses were previously grinded by a cross beater mill SK 100 (Retsch, Haan, Germany) for characterization analyses and sorption evaluations; the standard sorbent materials used in this work have a particle size of $0.1 \mathrm{~mm}<\mathrm{Sp}<0.5 \mathrm{~mm}$. The average particle size (Sp) of the materials was verified through a MASTERSIZER $3000^{\mathrm{TM}}$ equipment from Malvern Instruments, Ltd, UK.

\subsubsection{Scanning electron microscopy}

The samples were analyzed using a Philips XL-30 microscope (Philips Electron Optics, BV, Eindhoven-The Netherlands); the specialized scanning electron microscope (SEM) with low-vacuum and high-vacuum modes, is capable of analyzing samples under low pressure $\left(<5 \times 10^{-4} \mathrm{~Pa}\right)$. The objective lenses of the XL series have optimum performance for both imaging and micro-analysis of specimens; this 


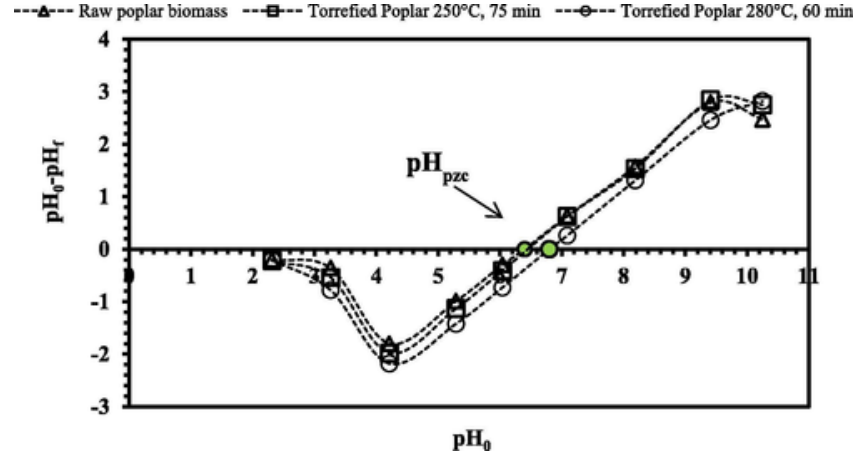

Fig. 7. Point of zero charge of the poplar-based materials. (T: $20^{\circ} \mathrm{C}$; V: $0.05 \mathrm{~L} ; \mathrm{m}: 0.1 \mathrm{~g}$; agitation speed: $150 \mathrm{rpm}$; contact time: $24 \mathrm{~h} ; \mathrm{pH}_{0}: 1-10.5 ; 0.1 \mathrm{M} \mathrm{NaCl}$ ).

a)

$\Delta$ Raw Poplar $\square$ Torrefied Poplar $250^{\circ} \mathrm{C}, 75 \mathrm{~min}$ OTorrefied Poplar $280^{\circ} \mathrm{C}, 60 \mathrm{~min}$

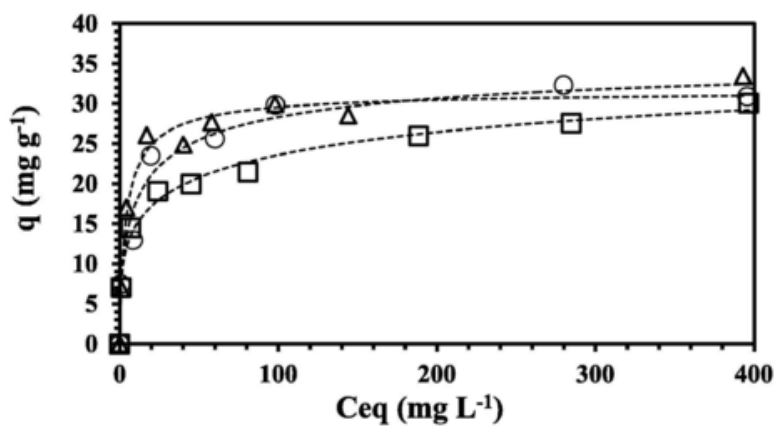

b)

$\Delta$ Raw Poplar aTorrefied Poplar $250^{\circ} \mathrm{C}, 75 \mathrm{~min}$ OTorrefied Poplar $280^{\circ} \mathrm{C}, 60 \mathrm{~min}$

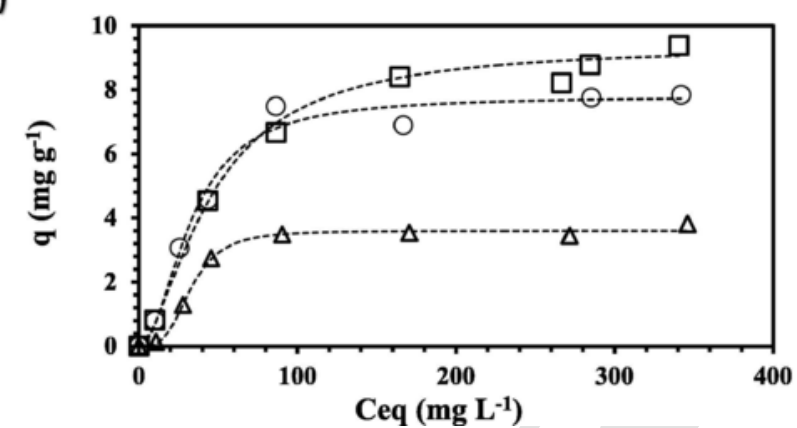

Fig. 8. Isotherm plots for target metals using poplar-based materials as sorbents. a) Sorption of $\mathrm{Pb}(\mathrm{II})$. b) Sorption of $\mathrm{Tb}(\mathrm{III})$. (Solid line: Sips model; $\mathrm{T}: 20^{\circ} \mathrm{C}$; sorbent dosage, SD: $1 \mathrm{~g} \mathrm{~L}^{-1}$; agitation speed: $150 \mathrm{rpm}$; contact time: $24 \mathrm{~h} ; \mathrm{pH}: 4 ; \mathrm{C}_{0}: 10-400 \mathrm{mg} \mathrm{L}^{-1}$ ).

makes ideal for the monitoring of manufacturing processes, as well as for routine operations. A high magnification is easily obtained (which improves the study of several types of micro/nano-structures). The microscope is also equipped with an Energy Dispersive X-ray (EDX) spectrometer (INCA 250, Oxford instruments) for chemical analyses.

The sorbent samples were analyzed before and after sorption of metals from aqueous solutions; EDX-analyses technique was used to detect the main elements present at the surface of the sorbent particles.

\subsubsection{FTIR analyses}

Fourier transform infrared (FTIR) analyses were performed using a BRUKER IFS 66 FTIR spectrophotometer equipped with a reflection diamond accessory (platinum ATR), and the spectra were recorded in the range of $4000-600 \mathrm{~cm}^{-1}$ with a sample amount of $2 \mathrm{mg}$ of biomass.

\subsubsection{TGA}

Thermal-gravimetric analyses were performed under $\mathrm{N}_{2}$ atmosphere (with a flow rate of $50 \mathrm{~mL} \mathrm{~min}^{-1}$ ) at a heating rate of $10^{\circ} \mathrm{Cmin}^{-1}$ using a SETSYS evolution TGA (SETARAM instrumentation, Caluire-et-Cuire, France). The samples of $5 \mathrm{mg}$ were degraded within a temperature range of $30-300^{\circ} \mathrm{C}$

\subsubsection{Elemental analyses}

Elemental analyses were conducted with a Vario EL cube instrument (ELEMENTAR, Langenselbold, Germany). The weight content of the main elements (such as carbon, hydrogen, nitrogen and sulfur) was determined by the equipment in three replicated analyses to validate the repeatability of the results (the standard deviation was in the order of $\pm 5 \%$ ). The following standard procedures were used for determining the elemental composition of the materials [1]: i) Carbon: XP CEN/ TS 15104; ii) hydrogen: XP CEN/TS 15105; iii) nitrogen: XP CEN/TS 15107; iv) sulfur: XP CEN/TS 15289; v) ash content: XP 199 CEN/TS 14775 (total combustion of the samples at $550^{\circ} \mathrm{C}$ ). The oxygen content was calculated by difference after determination of $\mathrm{C}, \mathrm{H}, \mathrm{N}, \mathrm{S}$ elements and ash content.

Additionally, macromolecular concentrations of hemicellulose, cellulose and lignin was determined following the classical standard methods [1]: i) Hemicellulose (TAPPI standard T249 $\mathrm{cm}-85$ ); ii) cellulose (TAPPI standard T249 cm-85); iii) Klason lignin (TAPPI standard T222 om-83); iv) soluble lignin (TAPPI standard T222 om-84).

\subsubsection{Bomb calorimeter}

A 6200 isoperibol oxygen bomb calorimeter (Parr, Moline-Illinois, USA) was used for determining the higher heating values of the raw and torrefied biomass. The ignition of $1 \mathrm{~g}$ of dried samples under oxygen atmosphere was performed at 30 bar pressure. Benzoic acid (Merck, Darmstadt, Germany) was used for calibrating the heat capacity of the calorimeter [5,22]. The higher heating values (HHV) obtained with the equipment were additionally compared with the predicted values obtained from the equation suggested by Friedl et al. [23]:

$$
\begin{aligned}
\mathrm{HHV}= & 3.55 \mathrm{C}^{2}-232 \mathrm{C}-2230 \mathrm{H} \\
& +51.2 \mathrm{CH}+131 \mathrm{~N}+20600
\end{aligned}
$$

where HHV is the higher heating value expressed in $\mathrm{kJ} \mathrm{kg}^{-1} ; \mathrm{C}, \mathrm{H}$ and $\mathrm{N}$ are the mass content $(\% \mathrm{w} / \mathrm{w})$ of carbon, hydrogen and nitrogen, respectively.

\subsubsection{X-ray diffraction (XRD) analyses}

The crystallinity of the prepared sorbents was determined by powder X-ray diffraction (XRD). The patterns were measured from powdered samples in a Bragg-Brentano diffractometer D8 Focus (Bruker, Horsaalzentrum, Germany), with copper anticathode $\mathrm{CuK} \alpha$ radiation $(\lambda=1.54 \AA)$. All the samples were scanned in the $2 \theta$ range of $2-80^{\circ}$ at a scan rate $2^{\circ} \mathrm{min}^{-1}$.

The crystallinity index (CrI) of the materials was estimated as follows (Eq. (2)):

$\operatorname{CrI}(\%)=\frac{\left(\mathrm{I}_{22.5}-\mathrm{I}_{18.7}\right)}{\mathrm{I}_{22.5}} \times 100$

where $\mathrm{I}_{22.5}$ is the intensity at $2 \theta=22.5^{\circ}$ and $\mathrm{I}_{18.7}$ is the intensity at $2 \theta=18.7^{\circ}$.

\section{4. $p H$ effect}

The study of $\mathrm{pH}$-influence on metal sorption was performed by mixing $10 \mathrm{~mL}$ of dilute metal solution (i.e., $10 \mathrm{mgL}^{-1}$ ) with $10 \mathrm{mg}$ of poplar-based materials (i.e., sorbent dosage, SD $1 \mathrm{gL}^{-1}$ ) in $25 \mathrm{~mL}$ polyethylene flasks. The sorbents were previously dried in a laboratory oven at $40^{\circ} \mathrm{C}$ overnight, in order to remove the moisture content. Proton concentration of the solutions was adjusted using $0.1 \mathrm{M} \mathrm{HCl}$ or 
Table 3

Langmuir, Freundlich and Sips constants of poplar derived materials.

\begin{tabular}{|c|c|c|c|c|c|c|c|c|c|c|c|c|c|}
\hline Metal & Experimental & & Langmuir & & & & Freundlich & & & Sips & & & \\
\hline & Sorbent & $\begin{array}{l}q_{\exp } \\
\left(m g g^{-1}\right)\end{array}$ & $\begin{array}{l}\mathrm{q}_{\max } \\
\left(\mathrm{mgg}^{-1}\right)\end{array}$ & $\mathrm{b}\left(\mathrm{Lmg}^{-1}\right)$ & $r^{2}$ & $\begin{array}{l}q_{\max } \mathrm{b} \\
\left(\mathrm{Lg}^{-1}\right)\end{array}$ & $\begin{array}{l}\mathrm{K}_{\mathrm{F}} \\
\left(\mathrm{mg}^{1-1 / n} \mathrm{~g}^{-1} \mathrm{~L}^{1 / \mathrm{n}}\right)\end{array}$ & $\mathrm{n}$ & $r^{2}$ & $\begin{array}{l}\mathrm{q}_{\max } \\
\left(\mathrm{mgg}^{-1}\right)\end{array}$ & $\mathrm{K}_{\mathrm{s}}\left(\mathrm{Lmg}^{-1}\right)$ & $\mathrm{n}_{\mathrm{s}}$ & $r^{2}$ \\
\hline \multirow[t]{3}{*}{$\mathrm{Pb}(\mathrm{II})$} & Raw Poplar & 28.50 & 30.50 & 0.26 & 0.970 & 7.93 & 12.94 & 5.87 & 0.909 & 31.68 & 0.3019 & 1.204 & 0.973 \\
\hline & $\begin{array}{l}\text { Torrefied } \\
\text { Poplar } 250{ }^{\circ} \mathrm{C} \text {, } \\
75 \text { min }\end{array}$ & 27.55 & 26.67 & 0.14 & 0.919 & 3.73 & 9.31 & 5.11 & 0.986 & 49.29 & 0.197 & 2.989 & 0.989 \\
\hline & $\begin{array}{l}\text { Torrefied } \\
\text { Poplar } 280^{\circ} \mathrm{C} \text {, } \\
60 \mathrm{~min}\end{array}$ & 30.89 & 32.09 & 0.11 & 0.947 & 3.53 & 11.28 & 5.38 & 0.929 & 37.27 & 0.250 & 1.813 & 0.960 \\
\hline \multirow[t]{3}{*}{$\mathrm{Tb}(\mathrm{III})$} & Raw Poplar & 3.80 & 4.40 & $2.22 \times 10^{-2}$ & 0.909 & 0.10 & 0.527 & 2.84 & 0.802 & 3.60 & $6.57 \times 10^{-6}$ & 0.293 & 0.994 \\
\hline & $\begin{array}{l}\text { Torrefied } \\
\text { Poplar } 250{ }^{\circ} \mathrm{C} \text {, } \\
75 \mathrm{~min}\end{array}$ & 9.38 & 10.96 & $1.68 \times 10^{-2}$ & 0.969 & 0.18 & 1.03 & 2.58 & 0.910 & 9.40 & $1.84 \times 10^{-3}$ & 0.607 & 0.981 \\
\hline & $\begin{array}{l}\text { Torrefied } \\
\text { Poplar } 280^{\circ} \mathrm{C} \text {, } \\
60 \mathrm{~min}\end{array}$ & 7.84 & 9.14 & $2.28 \times 10^{-2}$ & 0.948 & 0.21 & 1.14 & 2.89 & 0.858 & 7.79 & $9.68 \times 10^{-4}$ & 0.504 & 0.980 \\
\hline
\end{tabular}

Table 4

Comparison of sorption capacities for several sorbents.

\begin{tabular}{|c|c|c|c|c|}
\hline Sorbent & $\mathrm{pH}$ & $\begin{array}{l}\mathrm{q}_{\max } \mathrm{Pb}(\mathrm{II}) \\
\left(\mathrm{mgg}^{-1}\right)\end{array}$ & $\begin{array}{l}\mathrm{q}_{\max \mathrm{Tb}(\mathrm{III})} \\
\left(\mathrm{mg} \mathrm{g}^{-1}\right)\end{array}$ & Authors \\
\hline $\begin{array}{l}\text { Polyethylenimine immobilized into commercial alginate and Fucus vesiculosus alginate beads (AF- } \\
\text { PEI beads) }\end{array}$ & 4.0 & 225.8 & - & Demey et al. [14] \\
\hline Magnetite nanorods & 5.5 & 112.86 & - & Karami [51] \\
\hline Raw poplar (trunk) & 4.0 & 28.50 & 3.80 & This work \\
\hline Torrefied poplar $\left(250^{\circ} \mathrm{C}, 75 \mathrm{~min}\right)$ & 4.0 & 27.55 & 9.38 & This work \\
\hline Torrefied poplar $\left(280^{\circ} \mathrm{C}, 60 \mathrm{~min}\right)$ & 4.0 & 30.89 & 7.84 & This work \\
\hline Acid activated Kaolinite & 5.7 & 12.1 & - & $\begin{array}{l}\text { Bhattacharyya and Sen-Gupta } \\
\text { [52] }\end{array}$ \\
\hline Raw poplar (branches) & 4.0 & 1.7 & - & Al-Masri et al. [53] \\
\hline Poly(hydroxyethylmethacrylate)-hydroxyapatite modified with phytic acid & 3 & - & 49.26 & Akkaya [54] \\
\hline Poly(dithiocarbamate) chelated resin & 3.95 & - & 27.5 & Miyazaki and Barnes [55] \\
\hline Hydroxyapatite as sorbent of Tb-ligands & 7.4 & - & 9.07 & Rill et al. [56] \\
\hline 2-Thenoyltrifluoroacetone supported onto polyurethane foam & 3.5 & - & 6.67 & Saeed and Rusheed [57] \\
\hline Calcined Transcarpathian clinoptilolite & 8.2 & - & 6.1 & Vasylechko et al. [43] \\
\hline
\end{tabular}

$0.1 \mathrm{M} \mathrm{NaOH}$ (as required); the evaluated range was set at $\mathrm{pH} 1-6$ (to prevent the metal precipitation in all experimental series) and the stirring speed was set at $150 \mathrm{rpm}$ at $20^{\circ} \mathrm{C}$, using an agitator Rotabit, J.P. Selecta (Spain). After $24 \mathrm{~h}$ of agitation, the equilibrium $\mathrm{pH}$ was measured using a pH-meter from Jenco instruments (Arjons drive-San Diego, USA), and $5 \mathrm{~mL}$ of solution were filtered and analyzed with 4100 MP-AES instrument (Microwave plasma-atomic emission spectrometer from Agilent technologies, Santa Clara, USA) at the wavelengths of $405.78 \mathrm{~nm}$ and $350.91 \mathrm{~nm}$ for lead and terbium detection, respectively.

\subsection{Equilibrium sorption}

Sorption isotherms were obtained by mixing $10 \mathrm{~mL}$ of solution with different metal concentrations at $\mathrm{pH} 4$ and $10 \mathrm{mg}$ of sorbent (i.e., SD $\left.1 \mathrm{gL}^{-1}\right)$. After $24 \mathrm{~h}$ of contact time, the $\mathrm{pH}$ of the solutions was measured and the initial and equilibrium metal concentrations were systematically determined using 4100 MP-AES equipment. Three sorption replicates were performed for each experimental condition, and the standard deviation was in the order $\pm 5 \%$.

The Langmuir, the Freundlich and the Sips equations were used to describe the experimental sorption isotherm data [24-26]:

$q=\frac{q_{\max } b C_{e q}}{1+b C_{e q}}$
$\mathrm{q}=\mathrm{K}_{\mathrm{F}} \mathrm{C}_{\mathrm{eq}}^{1 / \mathrm{n}}$

$\mathrm{q}=\frac{\mathrm{q}_{\max } \mathrm{K}_{\mathrm{S}} \mathrm{C}_{\mathrm{eq}}{ }^{1 / \mathrm{ns}}}{1+\mathrm{K}_{\mathrm{S}} \mathrm{C}_{\mathrm{eq}}{ }^{1 / \mathrm{ns}}}$

where $q$ is the amount of sorbed metal per gram of sorbent at equilibrium $\left(\mathrm{mg} \cdot \mathrm{g}^{-1}\right), q_{\max }$ is the maximum sorption capacity of the sorbent (mg. $\mathrm{g}^{-1}$ ), and $C_{e q}$ is the equilibrium concentration of the solution (mg L ${ }^{-1}$ ). In the Langmuir model (Eq.(3)), $b$ is related to the energy of sorption $\left(\mathrm{L} \cdot \mathrm{mg}^{-1}\right)$, whereas $K_{F}$ and $n$ are the Freundlich sorption constants, indicative of the relative capacity and the sorption intensity, respectively; $\mathrm{K}_{\mathrm{s}}\left(\mathrm{L} \mathrm{mg}^{-1}\right)$ and $\mathrm{n}_{\mathrm{s}}$ are the constants of Sips model [26].

\subsection{Influence of contact time}

The uptake kinetics experiments were performed by adding (under continuous stirring) a known amount of sorbent (SD $1 \mathrm{gL}^{-1}$ ) to $500 \mathrm{~mL}$ of metal solution (i.e., $10 \mathrm{mg} \cdot \mathrm{L}^{-1}$ ) at $\mathrm{pH} 4$. Aliquots of solution were withdrawn at different times and filtered during $24 \mathrm{~h}$ of contact with the sorbents. The residual concentration was determined by 4100 MP-AES instrument. The kinetic profiles were built by using sorbent particles $(0.1 \mathrm{~mm}<\mathrm{Sp}<0.5 \mathrm{~mm})$ in order to evaluate the effect of the torrefaction conditions on the required contact time. The models such as PFORE and PSORE (pseudo-first order and pseudo-second order rate equations) were evaluated to fit the experimental data: 

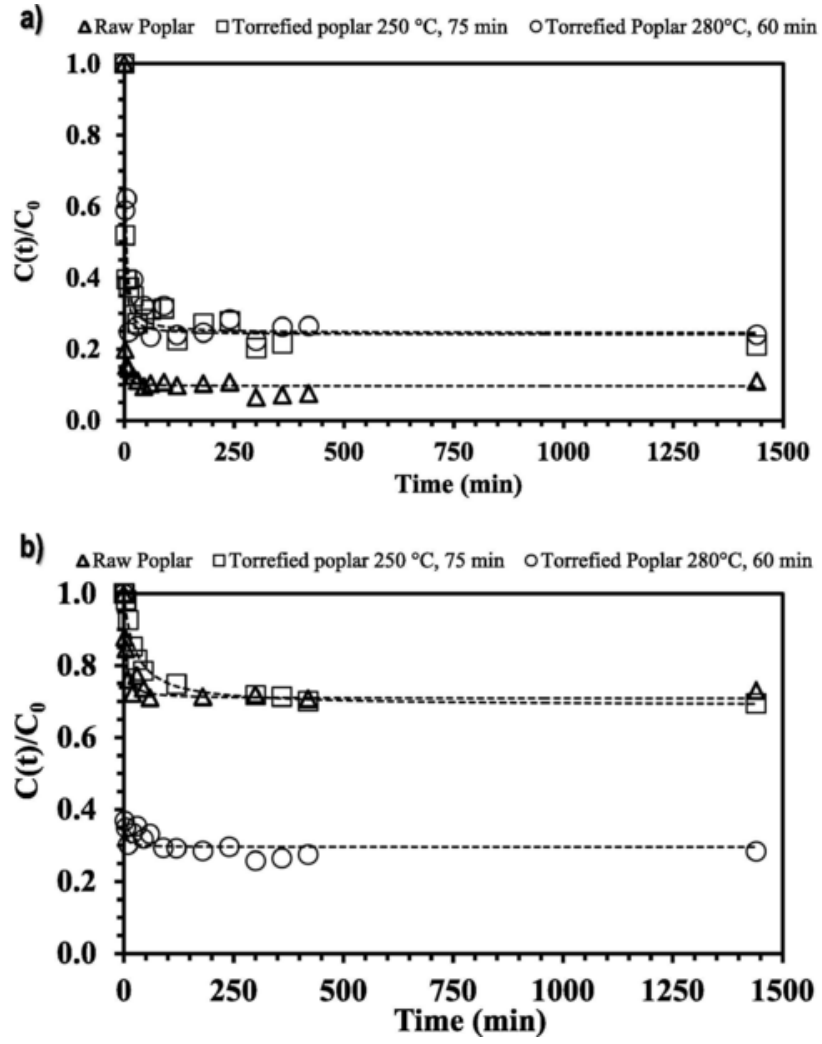

Fig. 9. Effect of contact time on sorption performance. a) Sorption of $\mathrm{Pb}(\mathrm{II})$. b) Sorption of $\mathrm{Tb}(\mathrm{III})$. (Dashed line: PSORE model; $\mathrm{T}: 20^{\circ} \mathrm{C}$; sorbent dosage, SD: $1 \mathrm{gL}^{-1}$; agitation speed: $150 \mathrm{rpm}$; contact time: $24 \mathrm{~h}$; $\mathrm{pH}: 4 ; \mathrm{C}_{0}: 10 \mathrm{mg} \mathrm{L}^{-1}$ ).

Pseudo-first order rate equation (PFORE) [27]:

$\frac{\mathrm{dq}_{\mathrm{t}}}{\mathrm{d}_{\mathrm{t}}}=\mathrm{K}_{1}\left(\mathrm{q}_{1}-\mathrm{q}_{\mathrm{t}}\right)$

Pseudo-second order rate equation (PSORE) [28]:

$\frac{\mathrm{dq}_{\mathrm{t}}}{\left(\mathrm{q}_{\mathrm{eq}}-\mathrm{q}_{\mathrm{t}}\right)^{2}}=\mathrm{K}_{2} \mathrm{~d}_{\mathrm{t}}$

where $q_{\mathrm{eq}}$ is the equilibrium sorption capacity (mg. $\mathrm{g}^{-1}$ ), $q_{t}$ is the sorption capacity $\left(\mathrm{mg} \cdot \mathrm{g}^{-1}\right)$ at any time $t(\mathrm{~min})$ and $k_{2}$ is the pseudo-second order rate constant $\left(\mathrm{g} \cdot \mathrm{mg}^{-1} \cdot \mathrm{min}^{-1}\right)$. The parameters $q_{\mathrm{eq}}$ and $k_{2}$ are pseudo-constants depending on the experimental conditions.

\subsection{Sorption-desorption cycles and selectivity study}

The reusability of the sorbents was tested using bi-component solutions of the target metals at equimolar concentrations $\left(0.05 \mathrm{mmol} \mathrm{L}^{-1}\right.$ and $0.1 \mathrm{mmol} \mathrm{L}^{-1}$ ) at $\mathrm{pH}$ 4. The eluent used for metal recovery was $0.1 \mathrm{M} \mathrm{HNO}_{3}$ solution (the volume of solution was $25 \mathrm{~mL}$ ); the sorbent dosage of $1 \mathrm{gL}^{-1}$ was maintained in order to establish comparisons with the results obtained in the single system. The sorbents were rinsed with distilled water until $\mathrm{pH} 7$ after each desorption step; it allowed removing the excess of eluent on the sorbent surface previous to the next sorption cycle. The sorption and elution efficiencies (SE and EE, respectively) were determined by $\operatorname{SE}(\%)=\left(\left(\mathrm{C}_{0}-\mathrm{C}_{\mathrm{eq}}\right) / \mathrm{C}_{0}\right) * 100$ and $\mathrm{EE}(\%)=($ eluted mass/sorbed mass $) * 100[14]$.

The selectivity study was performed to evaluate the affinity of both terbium and lead ions in binary system under different sorption-desorption cycles. The separation coefficient was calculated as follows [29]:

$\mathrm{Kd}_{i}=\frac{\mathrm{C}_{0}-\mathrm{C}_{\mathrm{eq}}}{\mathrm{mC}_{0}} \mathrm{~V}$

$\mathrm{R}_{\mathrm{Pb} / \mathrm{Tb}}=\frac{\mathrm{Kd}_{\mathrm{Pb}}}{\mathrm{Kd}_{\mathrm{Tb}}}$

where $\mathrm{R}_{\mathrm{Pb} / \mathrm{Tb}}$ is the separation coefficient of $\mathrm{Pb}(\mathrm{II})$ and $\mathrm{Tb}(\mathrm{III})$; $\mathrm{kd}$ is the distribution coefficient $\left(\mathrm{Lg}^{-1}\right) ; \mathrm{C}_{\mathrm{o}}$ is initial metal concentration $\left(\mathrm{mg} \mathrm{L}^{-1}\right)$; $\mathrm{C}_{\mathrm{eq}}$ is the metal concentration at equilibrium $\left(\mathrm{mg} \mathrm{L}^{-1}\right) ; \mathrm{m}$ is the mass of the sorbent $(\mathrm{g})$; $\mathrm{V}$ is the volume of the solution (L).

\section{Results and discussion}

\subsection{Characterization}

\subsubsection{Characterization of the materials}

SEM micrographs were performed for examining the topography of the materials surface. Fig. 1 shows the morphology of the poplar biomass (before and after torrefaction); some cavities are found around the entire surface, which correspond to the natural vessels of the sap channels of Populus sp. The holes have an average diameter of $2.1 \mu \mathrm{m}$; it agrees with the findings recently reported by Ai et al. [30], who called these cavities as 'bordered pits' which are the regulators of the vascular system of trees; these are the responsible of ensuring the connection between the tracheids, and prevent the living tree from embolism. However, in this work the dimension of the cavities increased as a function of the torrefaction severity (Fig. $1 \mathrm{~b}$ and c); i.e., at harder torrefaction conditions, wider holes are obtained: $2.7-3.1 \mu \mathrm{m}$ at $250^{\circ} \mathrm{C}$, and $8.2-8.6 \mu \mathrm{m}$ at $280^{\circ} \mathrm{C}$. It can be explained by the vapor gas generated during the first step of torrefaction, which has an impact on the cavities dilation, becoming these larger than those of the original raw biomass. This fact could also impact on the diffusion mechanisms, since the resulting surfaces after torrefaction are relatively more opened for the transfer of sorbate molecules into the volume of the biomass.

EDX-analyses on different zones of the superficial area (Fig. 1: a.1, $a 2$, b1, b2, c1, c2); confirm the presence of the main elements of the biomass (as expected: carbon, oxygen, hydrogen), and the cartography analyses after sorption of lead suggest the homogenous distribution of the metal in the whole volume of the sorbents (Fig. 2); the metal is uniformly dispersed on the surface of the materials. No significant differences were found in the metal distribution of lead (in comparison with the raw biomass).

Table 5

Kinetic parameters of sorbent materials.

\begin{tabular}{|c|c|c|c|c|c|c|c|c|}
\hline Metal & Experimental & & PFORE & & & PSORE & & \\
\hline & Sorbent & $\mathrm{q}_{\exp }\left(\mathrm{mg} \mathrm{g}^{-1}\right)$ & $\mathrm{K}_{1}\left(\min ^{-1}\right)$ & $\mathrm{q}_{1}\left(\mathrm{mg} \mathrm{g}^{-1}\right)$ & $\mathrm{r}^{2}$ & $\mathrm{~K}_{2}\left(\mathrm{~g} \cdot \mathrm{mg}^{-1} \cdot \mathrm{min}^{-1}\right)$ & $\mathrm{q}_{2}\left(\mathrm{mg} \mathrm{g}^{-1}\right)$ & $\mathrm{r}^{2}$ \\
\hline \multirow[t]{3}{*}{$\mathrm{Pb}(\mathrm{II})$} & Raw Poplar & 6.93 & 1.11 & 6.68 & 0.988 & 0.51 & 6.75 & 0.995 \\
\hline & Torrefied Poplar $250^{\circ} \mathrm{C}, 75 \mathrm{~min}$ & 6.21 & 0.44 & 5.49 & 0.901 & 0.13 & 5.67 & 0.946 \\
\hline & Torrefied Poplar $280^{\circ} \mathrm{C}, 60 \mathrm{~min}$ & 6.52 & 0.25 & 5.92 & 0.883 & $7.12 \times 10^{-2}$ & 6.11 & 0.904 \\
\hline \multirow[t]{3}{*}{$\mathrm{Tb}(\mathrm{III})$} & Raw Poplar & 2.05 & 0.19 & 1.89 & 0.941 & 0.16 & 1.99 & 0.960 \\
\hline & Torrefied Poplar $250^{\circ} \mathrm{C}, 75 \mathrm{~min}$ & 2.06 & $3.12 \times 10^{-2}$ & 1.94 & 0.983 & $1.85 \times 10^{-2}$ & 2.11 & 0.989 \\
\hline & Torrefied Poplar $280^{\circ} \mathrm{C}, 60 \mathrm{~min}$ & 4.89 & 1.15 & 4.77 & 0.973 & 0.736 & 4.82 & 0.980 \\
\hline
\end{tabular}



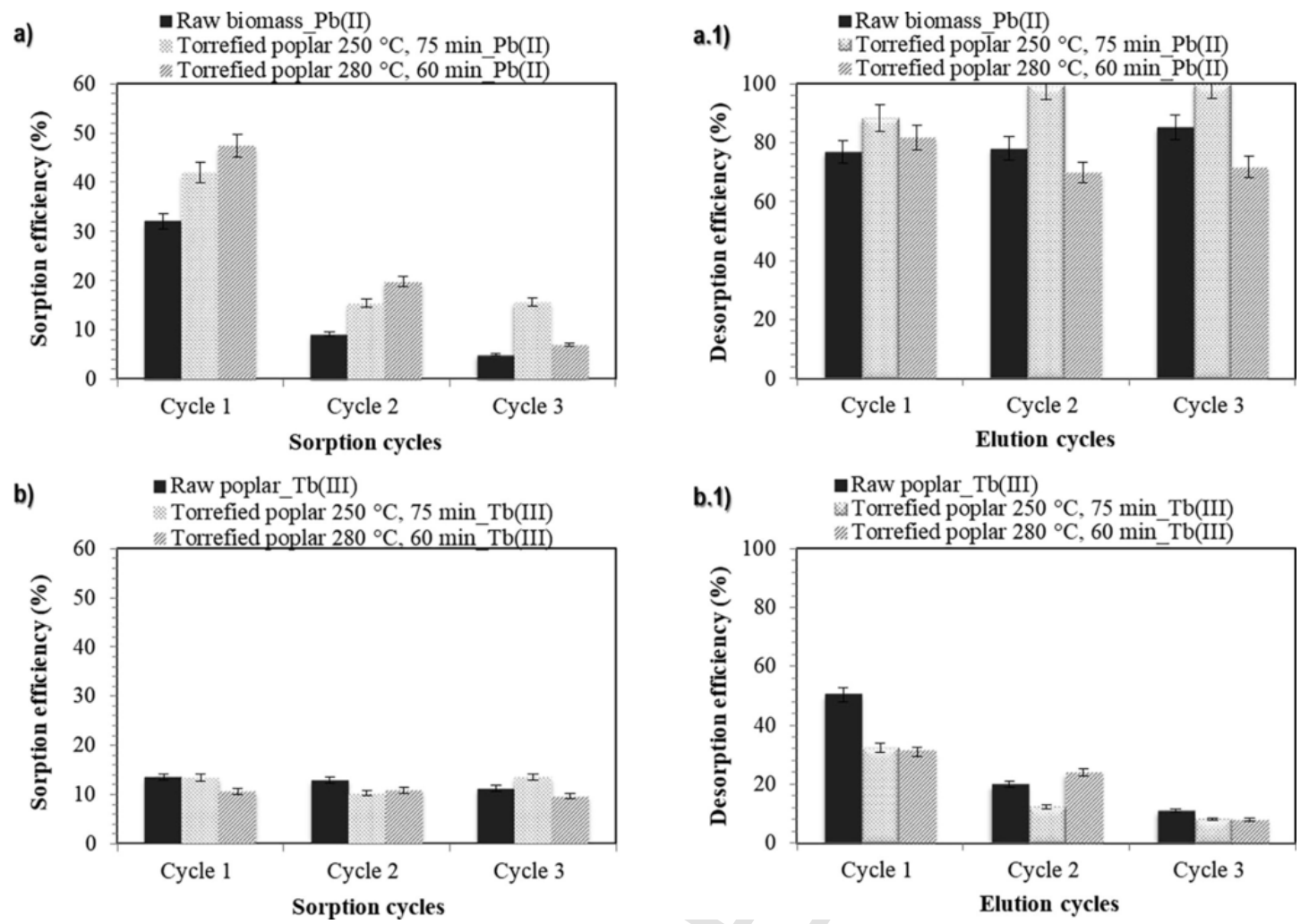

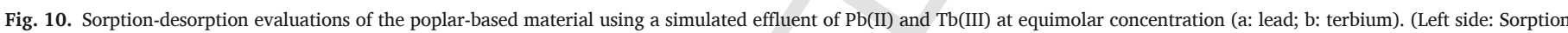
efficiency; T: $20^{\circ} \mathrm{C}$; SD: $1 \mathrm{~g} \mathrm{~L}^{-1}$; agitation speed: $150 \mathrm{rpm}$; contact time: $24 \mathrm{~h}$; $\mathrm{pH}: 4 ; \mathrm{C}_{0}: 0.05 \mathrm{mmol} \mathrm{L}^{-1}$; right side: Elution with $0.1 \mathrm{M} \mathrm{HNO}_{3}$ solution).

Table 6

Sorption and desorption cycles using multi-component solutions.

\begin{tabular}{|c|c|c|c|c|c|c|c|c|c|c|c|}
\hline Sorbent & $\begin{array}{l}\text { Metal concentration } \\
\left(\mathrm{mmolL}^{-1}\right)\end{array}$ & Metal & 1st Cycle & & & 2nd Cycle & & & 3rd Cycle & & \\
\hline & & & $\begin{array}{l}\text { Sorption } \\
\text { efficiency (\%) }\end{array}$ & $\begin{array}{l}\text { Elution } \\
\text { (\%) }\end{array}$ & $\mathrm{R}_{\mathrm{Pb} / \mathrm{Tb}}$ & $\begin{array}{l}\text { Sorption } \\
\text { efficiency (\%) }\end{array}$ & $\begin{array}{l}\text { Elution } \\
(\%)\end{array}$ & $\mathrm{R}_{\mathrm{Pb} / \mathrm{Tb}}$ & $\begin{array}{l}\text { Sorption } \\
\text { efficiency (\%) }\end{array}$ & $\begin{array}{l}\text { Elution } \\
\text { (\%) }\end{array}$ & $\mathrm{R}_{\mathrm{Pb} / \mathrm{Tb}}$ \\
\hline \multirow[t]{2}{*}{ Raw Poplar } & 0.05 & $\mathrm{~Pb}(\mathrm{II})$ & 32.10 & 76.90 & 2.38 & 9.10 & 78.06 & 0.70 & 4.97 & 85.29 & 0.44 \\
\hline & & $\mathrm{Tb}(\mathrm{III})$ & 13.51 & 50.38 & & 12.99 & 19.90 & & 11.24 & 11.07 & \\
\hline \multirow{2}{*}{$\begin{array}{r}\text { Torrefied Poplar } \\
250^{\circ} \mathrm{C}, 75 \mathrm{~min}\end{array}$} & & $\mathrm{~Pb}(\mathrm{II})$ & 41.95 & 88.35 & 3.13 & 15.42 & 99.80 & 1.50 & 15.67 & 99.85 & 1.16 \\
\hline & $\mathrm{Tb}(\mathrm{III})$ & & 13.40 & 32.31 & & 10.31 & 12.23 & & 13.51 & 8.11 & \\
\hline \multirow{2}{*}{$\begin{array}{r}\text { Torrefied Poplar } \\
280^{\circ} \mathrm{C}, 60 \mathrm{~min}\end{array}$} & & $\mathrm{~Pb}(\mathrm{II})$ & 47.43 & 81.71 & 4.47 & 19.80 & 69.82 & 1.83 & 6.99 & 71.89 & 0.72 \\
\hline & $\mathrm{Tb}(\mathrm{III})$ & - & 10.62 & 31.07 & & 10.82 & 23.86 & & 9.69 & 7.89 & \\
\hline \multirow[t]{2}{*}{ Raw Poplar } & 0.1 & $\mathrm{~Pb}(\mathrm{II})$ & 13.76 & 81.70 & 1.24 & 11.99 & 56.05 & 1.07 & 10.05 & 46.45 & 0.80 \\
\hline & & $\mathrm{Tb}(\mathrm{III})$ & 11.08 & 30.41 & & 11.23 & 12.84 & & 12.58 & 8.67 & \\
\hline \multirow{2}{*}{$\begin{array}{r}\text { Torrefied Poplar } \\
250^{\circ} \mathrm{C}, 75 \mathrm{~min}\end{array}$} & & $\mathrm{~Pb}(\mathrm{II})$ & 28.05 & 93.79 & 2.04 & 15.09 & 82.62 & 1.28 & 10.71 & 72.33 & 1.09 \\
\hline & $\mathrm{Tb}(\mathrm{III})$ & & 13.77 & 19.63 & & 11.79 & 6.76 & & 9.80 & 6.54 & \\
\hline \multirow{2}{*}{$\begin{array}{r}\text { Torrefied Poplar } \\
280^{\circ} \mathrm{C}, 60 \mathrm{~min}\end{array}$} & & $\mathrm{~Pb}$ (II) & 33.55 & 88.36 & 3.41 & 15.47 & 69.38 & 1.52 & 13.48 & 68.63 & 1.61 \\
\hline & $\mathrm{Tb}(\mathrm{III})$ & & 9.84 & 30.85 & & 10.20 & 3.82 & & 8.35 & 7.88 & \\
\hline
\end{tabular}

The observations of Ahmad et al. [31] on the morphology of torrefied biomass (empty fruit bunch) corroborate the formation of porous structures with increasing the severity torrefaction conditions. This fact has been directly correlated to the thermal decomposition of hemicellulose, cellulose and lignin content (especially cellulose and hemicellulose which start decompose at $220^{\circ} \mathrm{C}$ and $230^{\circ} \mathrm{C}$, respectively, whereas lignin decomposition takes place at low rate in a wide temperature range (from $250^{\circ} \mathrm{C}$ to $600^{\circ} \mathrm{C}$ ) $[22,32]$.

Fourier-transform infrared technique was used for studying the impact of the torrefaction conditions on the structure of the typical func- tional groups of the biomass. FTIR spectra were performed on the resulting samples of each torrefaction severity. The main functional groups of the Populus sp. biomass were identified (Fig. SM1 of the Supplementary materials section): the strong band centered at $3380-3600 \mathrm{~cm}^{-1}$ is attributed to $-\mathrm{OH}$ groups, which are present in the whole structure of hemicellulose and cellulose components [33]. The peak centered at $2910 \mathrm{~cm}^{-1}$ is associated with the $-\mathrm{CH}-$ stretching vibration of the polymeric chain; the band at $1740 \mathrm{~cm}^{-1}$ are related to the $\mathrm{C}=\mathrm{O}$ stretching. The bands around $1590-1600 \mathrm{~cm}^{-1}$ and $1420 \mathrm{~cm}^{-1}$ are attributed to the asymmetrical and symmetrical stretching of carboxylic groups; the bands at $1200 \mathrm{~cm}^{-1}$ and $1000-1034 \mathrm{~cm}^{-1}$ are assigned to 
C-O-C and $-\mathrm{C}-\mathrm{O}$ stretching, respectively. The peaks at $890 \mathrm{~cm}^{-1}$ are typically attributed to the $\mathrm{C}-\mathrm{H}$ bending of aromatic compounds [31].

No significant changes have been identified between the samples of raw biomass and those of the mild torrefaction at $250^{\circ} \mathrm{C}$, which could indicate a slight degradation of the main functional groups. In turn, the spectra of the torrefied material obtained at $280^{\circ} \mathrm{C}$ have some variations in comparison with the initial biomass: e.g., the peak at $1740 \mathrm{~cm}^{-1}$ was displaced to $1690 \mathrm{~cm}^{-1}$ which indicated the partial decomposition of the polymeric units.

The X-ray diffraction patterns of the raw poplar, torrefied poplar at $250^{\circ} \mathrm{C}$, and torrefied poplar at $280^{\circ} \mathrm{C}$ are shown in Fig. SM2. The patterns have a similar trend; two characteristics peaks have been identified around $2 \theta=18^{\circ}$ and $2 \theta=22.5^{\circ}$, which correspond to the diffractions of the planes $\left(\begin{array}{ll}1 & 0 \\ 1\end{array}\right)$ and $\left(\begin{array}{lll}0 & 0\end{array}\right)$ of the cellulose I and cellulose II, respectively [34]. The crystallinity index value (CrI) of the poplar biomass decreases with an increase of the torrefaction temperature, it was estimated as $40.9 \%$ for raw biomass, and it decreases to $36.7 \%$ at $250{ }^{\circ} \mathrm{C}$, and to $23.6 \%$ at $280^{\circ} \mathrm{C}$. These results are in agreement with the findings of Li et al. [34] and confirm that a fraction of both crystalline and amorphous cellulose is degraded at $280^{\circ} \mathrm{C}$.

\subsection{Torrefaction tests}

\subsubsection{Mass yields}

Before using the torrefaction pilot-plant oven (CENTORRE), some previous laboratory-scale experiments were performed in a TGA-equipment in order to predict the biomass stability over a range of temperatures (under nitrogen atmosphere); the ratio of the mass loss as a function of the temperature was quantified. The thermal degradation of the Populus sp. started at approximately $200^{\circ} \mathrm{C}$ with a slight weight loss of $1 \% \mathrm{w} / \mathrm{w}$ (Fig. 3) and it increased to $4.2 \% \mathrm{w} / \mathrm{w}$ at $250^{\circ} \mathrm{C}$; it can be due to the water evaporation of the samples, which initially contained over $4.5 \% \mathrm{w} / \mathrm{w}$ of moisture. From temperatures above $250{ }^{\circ} \mathrm{C}$, the weight loss curve is steeper, achieving $24.7 \% \mathrm{w} / \mathrm{w}$ at $250{ }^{\circ} \mathrm{C}, 51.2 \% \mathrm{w} / \mathrm{w}$ at $280^{\circ} \mathrm{C}$ and $64.4 \% \mathrm{w} / \mathrm{w}$ at $300^{\circ} \mathrm{C}$; it corresponds mainly to the partial decomposition of the hemicellulose and cellulose chains. The results are in concordance with those obtained by Jiang et al. [35] which studied the extraction and characterization of hemicellulose from hybrid poplar species; the authors reported an important weight loss in the order of $33-45 \%$ (at a temperature range of $230-325^{\circ} \mathrm{C}$ ). The extracted hemicelluloses were found to be rich in xylose content $(>79 \%)$, and just a small fraction of glucuronic acid was quantified $(<6.2 \%)$; the formation of non-combustible gases (such as $\mathrm{CO}, \mathrm{CO}_{2}$ ), formic acid and acetic acid were attributed to the conversion of the polysaccharides.

The study performed by Leal et al. [36] confirmed that cellulose compounds decompose in the temperature range of $220-480^{\circ} \mathrm{C}$; it means that both fractions of cellulose and hemicellulose are impacted in a close temperature interval. Table 1 reports the variation of the macromolecular content of poplar materials; the hemicellulose composition was the most affected; it shut down from $21.75 \%$ to $10.39 \%$ at $250^{\circ} \mathrm{C}$, and from $21.75 \%$ to $3.59 \%$ at $280^{\circ} \mathrm{C}$. The cellulose content slightly increased at $250^{\circ} \mathrm{C}$, as a result of the rapid degradation of hemicellulose, and it dramatically decreased at $280^{\circ} \mathrm{C}$ (from $42.72 \%$ to $23.93 \%$ ). This is attributed to the thermal conversion into condensable and non-condensable gases, and as expected, the lignin content was concentrated from $26.91 \%$ to $68.58 \%$, at $280^{\circ} \mathrm{C}$.

The mass yield of the biomass depends on the temperature and on the residence time of the samples into the torrefaction furnace. Thus, for characterizing the weight loss of the biomass as a function of these parameters, the kinetic profiles were plotted with temperatures set at $250{ }^{\circ} \mathrm{C}$, $280^{\circ} \mathrm{C}$ and $300^{\circ} \mathrm{C}$; the results in Fig. 3 show that increasing the torrefaction time, the mass loss increases until a pseudo-plateau is achieved. The curves have the typical shape of the pseudo-first order reaction plots.
The Lagergreen model [27] has been adapted and tested for describing the thermal-conversion of the biomass in the range of temperatures of $200-300^{\circ} \mathrm{C}$. Although the principles of the original model are completely different, the equation defines the kinetic profiles as a progressive rate in which an equilibrium time is reached. It is noteworthy that at $200-300^{\circ} \mathrm{C}$, the hemicellulose and cellulose decomposition plays an important role in the biomass upgrading, and the curves have a characteristic plateau in this interval, thus, for temperatures greater than $300^{\circ} \mathrm{C}$, in which the lignin degradation is more important, the Lagergreen model could fail since a second pseudo-plateau is formed.

The relative mass loss $\left(\mathrm{W}_{\mathrm{t}}\right)$ is defined as the ratio between the mass at the time $\mathrm{t}\left(\mathrm{m}_{\mathrm{t}}\right)$ and the initial mass of the sample $\left(\mathrm{m}_{0}\right)$ :

$\mathrm{W}_{t}=100-\frac{m_{t}}{\mathrm{~m}_{0}}$

Similarly, the relative mass loss at the equilibrium time $\left(\mathrm{W}_{\mathrm{p}}\right)$ is defined as the ratio $(\% \mathrm{w} / \mathrm{w})$ between the mass at the plateau $\left(\mathrm{m}_{\mathrm{p}}\right)$ and the initial mass of the sample $\left(\mathrm{m}_{0}\right)$ :

$\mathrm{W}_{p}=100-\frac{m_{p}}{\mathrm{~m}_{0}}$

The variation of the relative mass loss as a function of the time is defined as follows:

$\frac{\mathrm{dW}_{\mathrm{t}}}{\mathrm{d}_{\mathrm{t}}}=\mathrm{K}\left(\mathrm{W}_{p}-\mathrm{W}_{t}\right)$

where $\mathrm{K}$ is the kinetic constant expressed in $\mathrm{min}^{-1}$, $\mathrm{t}$ is the torrefaction time expressed in min, and the mass of the samples is expressed in $\mathrm{mg}$. Eq. (12) states that the rate of thermal-conversion is directly proportional to the distance to the plateau $\left(\mathrm{W}_{\mathrm{p}}-\mathrm{W}_{\mathrm{t}}\right)$, such distance is higher at time $\mathrm{t}=0$, in which $\mathrm{W}_{\mathrm{t}}=0$, and decreases with the time until the equilibrium is reached, $\mathrm{W}_{\mathrm{p}}-\mathrm{W}_{\mathrm{t}}=0$. The integration of Eq. (12) gives:

$\mathrm{W}_{\mathrm{t}}=\mathrm{W}_{\mathrm{P}}\left(1-e^{-K t}\right)$

The constants obtained from the model are reported in Table 2, the temperature has a greater impact on the mass yield of Populus sp. than the torrefaction time. The mass losses in the pseudo-plateau were estimated with Eq. (13) as $23.6 \% \mathrm{w} / \mathrm{w}, 51.2 \% \mathrm{w} / \mathrm{w}$ and $64.0 \% \mathrm{w} / \mathrm{w}$, at $250^{\circ} \mathrm{C}, 280^{\circ} \mathrm{C}$ and $300^{\circ} \mathrm{C}$, respectively.

The optimization of the processes is necessary in all industrial applications since it allows saving time and improves the reproducibility of the results; therefore, the fitting of the kinetics data provide useful information for predicting the impact of the residence time on the mass yield. The suggested Eq. (13) can be used to make the relationship between the TGA (at laboratory scale) and a larger scale production furnace (e.g., multiple hearth furnace). This empirical equation should be taken into account for adjusting the data of the solid-fuel manufacturing from torrefaction plants. In this work, the mass yields obtained in the torrefaction pilot-plant (CENTORRE) correspond well with the TG analyses at the similar operation conditions: $20.9 \% \mathrm{w} / \mathrm{w}$ at $250{ }^{\circ} \mathrm{C}$ and $52.9 \% \mathrm{w} / \mathrm{w}$ at $280^{\circ} \mathrm{C}$ (Table 2). Figs. SM3.a and SM3.b report the mass balance of the pilot-plant process and the gas production, as a result of the torrefaction of poplar biomass: i) at $250^{\circ} \mathrm{C}, 7.6 \mathrm{kgh}^{-1}$ of condensable and $22.8 \mathrm{~kg} \mathrm{~h}^{-1}$ of non-condensable gas were produced; ii) at $280^{\circ} \mathrm{C}, 13.2 \mathrm{~kg} \mathrm{~h}^{-1}$ of condensable and $51.04 \mathrm{~kg} \mathrm{~h}^{-1}$ of non-condensable gas were produced. The experiments at $300^{\circ} \mathrm{C}$ were not performed in the pilot-plant, since the main goal of the torrefaction process is to build dense materials with high calorific content and with a low loss of mass [37].

\subsubsection{Energy yields and elemental analyses}

The upgrade of biomass into more calorific materials, by using lower input of energy has been the main scope of the researchers in the 
last five years [37]. The higher heating value (HHV) is the net enthalpy released by the materials when reacting with oxygen under isothermal conditions [38].

Typically, the temperature of torrefaction has a greater impact on mass and energy yields of the torrefied feedstock than the residence time [34]. Table 1 reports the HHV of Populus sp., the ash content and the elemental analysis (C, H, N, S, O) of the materials. As expected, at higher temperature the oxygen/carbon and hydrogen/carbon ratios decrease as a consequence of the formation of the by-products during the decomposition steps of hemicellulose and cellulose (into condensable and non-condensable gases). From the Van Krevelen plot (Fig. 4) the $\mathrm{O} / \mathrm{C}$ ratio is more affected than $\mathrm{H} / \mathrm{C}$ ratio (the $\mathrm{O} / \mathrm{C}$ uptake of the raw biomass decreased from 0.72 to 0.37 at $280^{\circ} \mathrm{C}$ ): the temperature contributes to the densification of carbon concentration, which also favors the building of energetically dense materials. The HHV increases from $18.6 \mathrm{MJ} \mathrm{kg}^{-1}$ (raw Populus sp.) to $20.9 \mathrm{MJ} \mathrm{kg}^{-1}$ at $250{ }^{\circ} \mathrm{C}$, and to $23.9 \mathrm{MJ} \mathrm{kg}^{-1}$ at $280^{\circ} \mathrm{C}$; these values can be compared with those obtained with the Eq. (1) suggested by Friedl et al. [23], in which the HHV is associated with the elemental composition of the materials; the proximity between the results (Table 1) indicates that Friedl equation can be used to calculate the HHV when the bomb calorimeter is not available.

In terms of energy, the manufactured solid-fuel at $280^{\circ} \mathrm{C}$ offers a greater calorific power than that manufactured at $250^{\circ} \mathrm{C}\left(3 \mathrm{MJ} \mathrm{kg}^{-1}\right.$ greater), but the mass loss is also higher (53\%) which potentially affects the economic feasibility of the system. In this way, the mass yield plays an important role in the process, since larger mass losses than 30\% w/ $\mathrm{w}$ are not convenient to make feasible the system for industrial exploitation [37]. Thus, the torrefied poplar at $250{ }^{\circ} \mathrm{C}$ (with a mass yield of $21 \%$ $\mathrm{w} / \mathrm{w}$ ) is the best material in this work for energy generation.

\subsection{Sorption evaluations}

\subsection{1. $p H$ effect}

The $\mathrm{pH}$ is the most relevant parameter of the sorption systems; the concentration of the protons directly impact on the sorbate-sorbent interactions which could improve and/or decrease the performance of the process (depending on the specific nature of the sorbent and on the metal species involved). The distribution of the metal species as a function of $\mathrm{pH}$ at dilute concentrations $\left(0.1 \mathrm{mmol} \mathrm{L}^{-1}\right)$ is represented in the Supplementary materials section (Fig. SM4). All the experiments of this work have been conducted to avoid the precipitation phenomenon: the speciation of the sorbate molecules into the solution was checked, and the $\mathrm{pH}$ was carefully monitored.

Figs. 5a and 6a show the removal of lead and terbium at different $\mathrm{pH}$ values; the manufactured materials at $250^{\circ} \mathrm{C}$ and $280^{\circ} \mathrm{C}$ were compared with the raw biomass. It can be noted that metal sorption is unfavorable at very acidic conditions; from $\mathrm{pH} 1$ to 3 the removal uptake is between 5 and $10 \%$ for both metals, and at $\mathrm{pH}$ above 4 the performance increases until reaching $94 \%$ for lead and $23 \%$ for terbium (at $\mathrm{pH}$ 6). The low yield at $\mathrm{pH}<3$ can be attributed to the strong competition between the protons and the metal cations for the active sites of the materials; this is in agreement with the Fig. $5 b$ and $6 b$, in which the final $\mathrm{pH}$ increases as a consequence of the $\mathrm{H}^{+}$binding with the functional groups. However, from $\mathrm{pH} \geq 4$ the concentration of protons is lower and the competition tends to decrease.

At $\mathrm{pH} 4-6$ a type of buffering effect is produced (regardless of the sorbent and regardless of the metal specie, Fig. $5 \mathrm{~b}$ and $6 \mathrm{~b}$ ); it agrees with the findings reported by Demey et al. [14,39] using algal-based sorbents for the removal of boron and heavy metals; this effect is associated to the protonation of carboxylic groups (present in Populus sp.) which impacts on the removal uptake. According to Haug [40], the pKa of COO- groups for standard samples varies between 3.38 and
3.65; i.e., for $\mathrm{pH}$ below 3.5 the carboxylic groups are protonated and the interaction with metal ions is negligible (low) [41].

Moreover, the $\mathrm{pH}$ values at which the materials surfaces have zero charge (so-called $\mathrm{pH}_{\mathrm{PZC}}$ ) were determined by the drift method [42]. The plots of the $\mathrm{pH}_{\mathrm{PZC}}$ are represented in Fig. 7; the values for raw biomass and torrefied poplar at $250^{\circ} \mathrm{C}(75 \mathrm{~min})$ were found to be as $\mathrm{pH} 6.4$, the curves are overlapped (the mild torrefaction does not strongly affect the $\mathrm{pH}_{\mathrm{PZC}}$ of the feedstock). However, for torrefied poplar at $280^{\circ} \mathrm{C}(60 \mathrm{~min})$ the $\mathrm{pH}_{\mathrm{PZC}}$ was found as $\mathrm{pH}$ 6.8. It means that at $\mathrm{pH}<\mathrm{pH}_{\mathrm{PZC}}$, the surfaces of the sorbents are positively charged and consequently the removal of cations species decreases at acidic $\mathrm{pH}$, since the repulsion forces make difficult the diffusion of the ions onto the active sites of the materials. Naturally, by increasing the $\mathrm{pH}$, the surfaces become more negative and the sorbate/sorbent attractions improve the sorption uptake of the metals.

It is noteworthy that the sorption ratio for lead is higher compared to that obtained with terbium at the same operation conditions (at equilibrium $\mathrm{pH}$ around 4.3-4.6, the sorption performance was between 85 and $90 \%$ for $\mathrm{Pb}(\mathrm{II})$ and between 6 and $12 \%$ for $\mathrm{Tb}(\mathrm{III})$ ); this is a first indication of the special selectivity toward $\mathrm{Pb}(\mathrm{II})$ ions. Upon increasing the $\mathrm{pH}$, the performance becomes more effective until reaching values in the order of $90-94 \%$ for lead and $15-23 \%$ for terbium at $\mathrm{pH} 6.3$; the results are in agreement with Vasylechko et al. [43], which indicated that at neutral $\mathrm{pH}$ conditions ( $\mathrm{pH}$ around 6.5-8.5) occurs the best sorption of terbium (at trace concentrations) on Transcarpathian clipnoptilolite material. These studies (Fig. 5.a and 6.a) also show that torrefaction treatment does not impact the sorption removal of the poplar-based materials, and it could be useful for conditioning the biomass, enhancing the grindability (i.e., reduction of the particle size) and making possible the storage of the sorbents for longer time (with not biological activity) [44]. In this work, the poplar-based materials tend to stabilize above $\mathrm{pH}$ 4; hence, this $\mathrm{pH}$ was chosen for carrying out the equilibrium studies.

\subsubsection{Equilibrium studies}

Isotherm curves are important for describing the distribution of the sorbate molecules between the liquid and solid phases at equilibrium conditions [45]. This is fundamental for understanding the metal/sorbent interactions, and it consolidates the characterization of the materials (in terms of maximum sorption capacity).

Fig. 8a and b compare the sorption isotherms of the torrefied poplar and the raw biomass; the curves show the presence of two typical steps: i) an initial step which is characterized by a very steep slope, and ii) a saturation plateau, which is achieved at high metal concentrations. The degree of the sorbent/metal affinity is associated to the steep of the first slope [46]. It is noteworthy that the system is very efficient at dilute metal concentrations $<20 \mathrm{mg} \mathrm{L}^{-1}$ (i.e., the sorbents remove more than $80 \%$ of initial lead and more than $20 \%$ of initial terbium content, respectively), meaning that the process is highly attractive for polishing industrial effluents from trace of inorganic pollutants; this contributes to reduce the operational costs of the primary coagulation-flocculation technique, and fortifies the environment sustainability, since the bio-based sorbents are naturally degradable [14].

The correlation of the data by the empirical equations is required for the design and further scaling-up of the sorption reactors. Several models were used for fitting the experimental data (Table 3). Sips equation allows describing with better accuracy the equilibrium results; this fitting does not necessarily mean that the process confirms the original hypotheses of the model (which include that values of $1 /$ ns close to 1 correspond to sorbents with homogenous binding sites); however it helps to characterize the shape of the isotherm curves, and it is useful for interpreting the metal binding. As seen in Table 3, the torrefied materials have similar sorption capacities toward $\mathrm{Pb}(\mathrm{II})$ ions in comparison with the raw biomass; it verifies the previous results ob- 
tained in the $\mathrm{pH}$ study: the mild torrefaction does not affect the performance of the sorbent materials. The maximum sorption uptake achieved was $30 \mathrm{mg} \mathrm{g}^{-1}$ for lead. Nevertheless, in the case of terbium, it seems that a high content of lignin and cellulose favors the removal of this metal; thus, the torrefied materials have better sorption uptake than the original raw biomass. The maximum sorption capacity improved from $3.8 \mathrm{mg} \mathrm{g}^{-1}$ of the raw biomass to $9.4 \mathrm{mg} \mathrm{g}^{-1}$ for torrefied poplar at $250^{\circ} \mathrm{C}$ (75 min) and $7.8 \mathrm{mg} \mathrm{g}^{-1}$ for torrefied poplar at $280^{\circ} \mathrm{C}(60 \mathrm{~min})$.

Moreover, in the Table 3 are represented the values of the affinity parameter $\mathrm{b}$ and the product $\mathrm{q}_{\max }{ }^{*} \mathrm{~b}$ (which is the initial slope of the isotherm curve); these are especially greater for lead than for terbium. It is a clear indicative of the higher selectivity toward $\mathrm{Pb}$ (II) ions. Thus, the sorption uptake follows the trend: $\mathrm{Pb}$ (II) $\gg \mathrm{Tb}$ (III), it can be due to several causes:

- Papageorgiou et al. [41] indicated that the binding uptake of the metals is associated with the valence orbital energy $\left(\mathrm{X}_{\mathrm{m}}{ }^{2} \mathrm{r}\right)$, where $\mathrm{X}_{\mathrm{m}}$ is the electronegativity (Pauling scale) and $\mathrm{r}$ is the covalent radius (pm units), the theoretical values of $\mathrm{X}_{\mathrm{m}}{ }^{2 *} \mathrm{r}$ were calculated as 531 and 279 for lead and terbium, respectively (i.e., $\mathrm{Xm}=1.90 ; \mathrm{r}=147 \mathrm{pm}$ for lead, and $\mathrm{Xm}=1.2 ; \mathrm{r}=194 \mathrm{pm}$ for terbium).

- Bohli et al. [47] reported that the sorption uptake follows the hydrolysis constant of the metal species, but it cannot be entirely verified in this work since the constant values are similar (pKh: 7.80 for $\mathrm{Pb}(\mathrm{II})$ and 7.64 for $\mathrm{Tb}(\mathrm{III})$ [48].

- The hard and soft bases-theory (so-called HSAB theory) [49], which is commonly referred to the higher interactions between hard acids with hard basis, and soft acids with soft basis. According to the Nieboer and Richardson classification [50], lead is considered as a borderline metal and can form bindings with elements of class A (oxygen-seeking) and class B (nitrogen/sulfur-seeking), without special preference for these species; however, terbium is considered as a hard acid (class A element) which partially limits the binding with hard basis, and consequently a lower amount of ligands of the sorbent can interact with these metal ions.

The comparison of the maximum sorption capacities with the materials of the recent literature is represented in Table 4; the torrefied materials have the same order of magnitude of the reported sorbents. Al-Masri et al. [53] studied the sorption of $\mathrm{Pb}(\mathrm{II})$ onto pulverized branches of raw poplar biomass, interestingly they founded a removal uptake of $1.7 \mathrm{mgg}^{-1}$; it is almost 17 times less than that obtained in this work with the trunk of the poplar tree, at the similar operation conditions ( $\mathrm{pH} 4$ ). This could be related to the fact that the branches of the trees have generally a lesser content of cellulose and lignin than the wood stem and trunk; consequently a lesser content of active sites is available for metal sorption, this is in agreement with Räisänen and Athanassiadis [58], and Samariha and Kiaei [59]. The cellulose composition of the different parts of the trees may also vary according to the geographical origins and weather conditions [59]. Al-Masri et al. [53] did not report the macromolecular and sugar content of their Populus specie branches, nevertheless, the predominant sugars present in our feedstock are the glucan and xylan monosaccharides (the content was determined as $44.4 \%$ and $14.6 \%$ in the trunk of the raw poplar, respectively). Table SM1 (Supplementary materials section) reports the variation of the monosaccharide composition of Populus sp. as a function of the torrefaction conditions. As expected, the sugar composition decreases with an increase of the torrefaction temperature; mannan, galactan and arabinan concentrations are almost negligible in the torrefied materials.

Despite Akkaya [54], Demey et al. [14], and Karami [51] have suggested sorbents with a higher sorption uptake for terbium and heavy metals (Table 4), the multiple steps and the complexity of the manufac- turing procedure should be taken into account for a major scaling-up of the process. The torrefied poplar-materials have as a main advantage that these are easy for production at large industrial scale: the process only needs a torrefaction and a grinding step for conditioning the raw biomass. Additionally, the torrefied sorbents are preferable over raw biomass, since these can be storage for a longer time [60].

\subsubsection{Influence of contact time}

The sorption kinetic study is important for determining the required contact time of the sorbate/sorbent systems and it allows improving the understanding of the dynamic sorption reactors [16]. Fig. 9.a and 9.b show the kinetic profiles for lead and terbium removal using the poplar-based materials as sorbents. The curves follow the same trend and three pseudo steps can be clearly identified (regardless of the sorbent). The difference on metal sorption of each step is related to the concentration gradient which decreases progressively with the time, making the mass transfer and the driving forces slower [13]: i) an initial step which is particularly fast and takes around 10-20 min for lead and $5-10 \mathrm{~min}$ for terbium ions (it represents $60-70 \%$ of the total sorption uptake); ii) a second step which takes around $20-60 \mathrm{~min}$ for lead and $10-20 \mathrm{~min}$ for terbium (it represents a contribution of $5-10 \%$ to the metal uptake); iii) a third slower step which takes around 60-90 min for lead and 20-60 min for terbium, it accounts for a lesser contribution to the sorption uptake $(<2 \%)$.

In this study, the sorption uptakes follow the sequence $\mathrm{Pb}(\mathrm{II}) \gg \mathrm{Tb}$ (III), confirming the results obtained with the isotherms data. The particle size plays an important role on the kinetic profiles, lower particle size involves that a higher surface area is available; as a result, the resistance to the external film diffusion is impacted [61] and the sorbate molecules can reach easily the active sites. The sorbents have approximately the same average particle size (i.e. $0.1 \mathrm{~mm}<\mathrm{Sp}<0.5 \mathrm{~mm}$ ), thus the required contact time for achieving the equilibrium can be compared under the same operation conditions (sorbent dosage, SD: $1 \mathrm{gL}^{-1}$, agitation speed: $150 \mathrm{rpm}$; contact time: $24 \mathrm{~h}$; $\mathrm{pH}$ : 4).

The materials reach the equilibrium faster with terbium than with lead species (i.e., $70 \mathrm{~min}$ for $\mathrm{Tb}(\mathrm{III})$ and $90 \mathrm{~min}$ for $\mathrm{Pb}(\mathrm{II})$ ). This slight difference can be due to several causes: i) the covalent radius of lead is greater than that of terbium, and these latter ions have no difficulties for transporting into the entrance of pores. As explained by Rorrer et al. [62], a blockage mechanism may occur at dilute metal concentrations, since the migration is low and the large size ions can be accumulated at the entrance of the pore. ii) A second cause (more evident in this study) is the higher affinity of the sorbents toward lead species which is also reflected in the sorption ratio ( $80-90 \%$ for lead, and $30-70 \%$ for terbium). According to HSAB theory, lead is a borderline metal, hence, there is not special preference for binding with class A and class B elements. Therefore more functional groups are compatible and can interact with $\mathrm{Pb}(\mathrm{II})$, and the complete saturation of all active sites can take longer time. Table 5 reports the comparison of the experimental sorption capacities at equilibrium with calculated values for both the pseudo-first order and the pseudo-second order rate equations (PFORE and PSORE, respectively); the correlation coefficients confirm a better fitting with PSORE.

\subsubsection{Reusability and selectivity of the sorbents}

The cost/efficiency of the sorbents is linked to their capacity of regeneration; i.e. a good sorbent must be recyclable in order to be economically competitive [63]. The regeneration of the poplar-based materials was demonstrated by three consecutive sorption-desorption cycles using bi-component solutions at equimolar concentrations of $0.05 \mathrm{mmol} \mathrm{L}^{-1}$ and $0.1 \mathrm{mmol} \mathrm{L}^{-1}$ of terbium and lead.

Based on the experimental data (Fig. 10a and b), the sorption efficiency values are three times greater for lead in comparison with those 
of terbium in the first cycle ( $47 \%$ for lead and $13 \%$ for terbium). The performances of the materials decrease progressively and become almost similar at the third sorption cycle, this is an indicative of the occupancy of the pores by the target metals and it evidences the exhaustion of the active sites during the sorption steps [64].

Table 6 compares the sorption and desorption efficiencies of $\mathrm{Pb}$ (II) and $\mathrm{Tb}(\mathrm{III})$ for three consecutive cycles. The trend was confirmed by using two different equimolar concentrations of metals; the solution of $0.1 \mathrm{M} \mathrm{HNO}_{3}$ was efficient for eluting the sorbed species; it can be recovered more than $80 \%$ of $\mathrm{Pb}(\mathrm{II})$ and more than $30 \%$ of terbium from the loaded sorbent (Fig. 10: a.1 and b.1), these values are referred to the initial sorbed amount of each sorption cycle. Moreover, the separation coefficient $\mathrm{R}_{\mathrm{Pb} / \mathrm{Tb}}$ demonstrated the greater selectivity toward $\mathrm{Pb}$ (II) ions, the torrefied poplar-based materials were found to be more selective than the raw biomass; the $\mathrm{R}_{\mathrm{Pb} / \mathrm{Tb}}$ values follow the sequence: torrefied poplar at $280^{\circ} \mathrm{C}(60 \mathrm{~min})>$ torrefied poplar at $250^{\circ} \mathrm{C}(75 \mathrm{~min})>$ raw biomass. This demonstrates the potential of the poplar-based sorbents for recovery of lead and terbium from real effluents, and it opens the doors for a real industrial application, which will be the scope of a future work.

\section{Conclusions}

Poplar-based materials are efficient for energy production and promising for lead and terbium recovery from waters. The torrefaction of the biomass contributes to increase the calorific content of the resulting products. It was found that the higher heating values increased from $18.42 \mathrm{MJ} \mathrm{kg}^{-1}$ (raw poplar biomass) to $20.90 \mathrm{MJ} \mathrm{kg}^{-1}$ and $23.90 \mathrm{MJ} \mathrm{kg}^{-1}$, for torrefied poplar at $250^{\circ} \mathrm{C}(75 \mathrm{~min})$ and $280^{\circ} \mathrm{C}(60 \mathrm{~min})$, respectively. The mass loss was strongly impacted as a function of the torrefaction conditions; it was achieved $21 \%$ at $250^{\circ} \mathrm{C}(75 \mathrm{~min})$ and $53 \%$ at $280^{\circ} \mathrm{C}$ (60 min), respectively. According to the characterization data, the mild torrefaction process allows the manufacturing of materials with a higher content of lignin and cellulose, which favors the sorption of metals from aqueous solutions. The maximum sorption capacities obtained were in the order of $30 \mathrm{mgg}^{-1}$ and $9.4 \mathrm{mg} \mathrm{g}^{-1}$ for lead and terbium, respectively. The Sips model and PSORE fitted accurately the sorption isotherms and the kinetic experimental data, respectively. The evaluations with simulated effluent of lead and terbium demonstrated the higher selectivity of sorbents toward lead ions in three consecutive sorption-desorption cycles. The materials can be efficiently eluted by using dilute $\mathrm{HNO}_{3}$ solution $(0.1 \mathrm{M})$.

\section{Acknowledgements}

This work was supported by the European Union's Horizon 2020 Research and Innovation Programme under grant agreement No 637020-MOBILE FLIP. The French agency for research (ANR) is acknowledged for partial funding of the GENEPI platform within the framework of the investments of future (Ref: ANR-11-EQPX-0019). The authors would like to thank Mr P. Pons de Vincent (from Commissariat à l'Energie Atomique et aux Energies Alternatives, Grenoble-France) for his technical assistance in this work. The Spanish Ministry and Competitiveness, MINECO (Ref: CTM2017-83581-R) is also acknowledged for partial financial support for terbium and lead analyses.

\section{Appendix A. Supplementary data}

Supplementary data to this article can be found online at https:// doi.org/10.1016/j.cej.2018.12.148.

\section{References}

[1] E. Rodriguez-Alonso, C. Dupont, L. Heux, D. Da Silva-Perez, J.M. Commandre, C Gourdon, Study of solid chemical evolution in torrefaction of different biomasses through solid-state ${ }^{13} \mathrm{C}$ cross-polarization/magic angle spinning NMR (nuclear magnetic resonance) and TGA (thermogravimetric analysis), Energy 97 (2016) 381-390.

[2] S. Ladanai, J. Vinterback, Global Potential of Sustainable Biomass for Energy, Report 013, Department of energy and Technology, Swedish University of Agricultural Sciences, Uppsala, 2009.

[3] T. Melkior, S. Jacob, G. Gerbaud, S. Hediger, L. Le Pape, L. Bonnefois, M. Bardet, NMR analysis of the transformation of wood constituents by torrefaction, Fuel 92 (1) (2012) 271-280.

[4] D. Medic, M. Darr, A. Shah, B. Potter, J. Zimmerman, Effects of torrefaction process parameters on biomass feedstock upgrading, Fuel 91 (1) (2012) 147-154

[5] B.S. Chiou, D. Valenzuela-Medina, C. Bilbao-Sainz, A.P. Klamczynski, R.J. Avena-Bustillos, R.R. Milczarek, W.X. Du, G.M. Glenn, W.J. Orts, Torrefaction of almond shells: effects of torrefaction conditions on properties of solid and condensate products, Ind. Crops Prod. 86 (2016) 40-48.

[6] M. Phanphanich, S. Mani, Impact of torrefaction on the grindability and fuel characteristics of forest biomass, Bioresour. Technol. 102 (2) (2011) 1246-1253.

[7] M.J. Prins, K.J. Ptasinski, F.J.J.G. Janssen, More efficient biomass gasification via torrefaction, Energy 31 (2016) 3458-3470.

[8] L. Wang, E. Barta-Rajnai, Ø. Skreiberg, R. Khalil, Z. Czégény, E. Jakab, Z. Barta, M. Grønli, Impact of torrefaction on woody biomass properties, Energy Procedia 105 (2017) 1149-1154.

[9] Z. Yang, S. Jia, T. Zhang, N. Zhuo, Y. Dong, W. Yang, Y. Wang, How heavy metals impact on flocculation of combined pollution of heavy metals - antibiotics: a comparative study, Sep. Purif. Technol. 149 (2015) 398-406.

[10] Z. Yang, S. Jia, N. Zhuo, W. Yang, Y. Wang, Flocculation of copper (II) and tetracycline from water using a novel $\mathrm{pH}$ - and temperature-responsive flocculants, Chemosphere 141 (2015) 112-119.

[11] M.T. Coll, A. Fortuny, C.S. Kedari, A.M. Sastre, Studies on the extraction of Co (II) and $\mathrm{Ni}$ (II) from aqueous chloride solutions using Primene JMT-Cyanex272 ionic liquid extractant, Hydrometallurgy 125-126 (2012) 24-28.

[12] S. Pavón, A. Fortuny, M.T. Coll, A.M. Sastre, Neodymium recovery from NdFeB magnet wastes using Primene 81 R Cyanex 572 IL by solvent extraction, J. Environ. Manage. 222 (2018) 359-367.

[13] H. Demey, B. Lapo, M. Ruiz, A. Fortuny, M. Marchand, A.M. Sastre, Neodymium recovery by chitosan/iron(III) hydroxide [chiFer(III)] sorbent material: batch and column systems, Polymers-Basel 10 (2) (2018) 204.

[14] H. Demey, T. Vincent, E. Guibal, A novel algal-based sorbent for heavy metal removal, Chem. Eng. J. 332 (2018) 582-595.

[15] A.A. Edathil, I. Shittu, J.H. Zain, F. Banat, Novel magnetic coffee waste nanocomposite as effective bioadsorbent for $\mathrm{Pb}$ (II) removal from aqueous solutions, J. Environ. Chem. Eng. 6 (2) (2018) 2390-2400.

[16] B. Lapo, H. Demey, J. Zapata, C. Romero, A.M. Sastre, Sorption of Hg(II) and Pb(II) ions on chitosan-iron(III) from aqueous solutions: single and binary systems, Polymers-Basel 10 (4) (2018) 367.

[17] Y.J. Tu, S.C. Lo, C.F. You, Selective and fast recovery of neodymium from seawater by magnetic iron oxide $\mathrm{Fe}_{3} \mathrm{O}_{4}$, Chem. Eng. J. 262 (2015) 966-972.

[18] U.S. Department of Energy, Critical materials strategy, advanced research projects agency-energy, Washington, DC, USA, 2011

[19] B. Bian, L. Zhang, Q. Zhang, S. Zhang, Z. Yang, W. Yang, Coupled heating/acidification pretreatment of chemical sludge for dewatering by using waste sulfuric acid at low temperature, Chemosphere 205 (2018) 260-266.

[20] L. Rosso, G. Facciotto, S. Bergante, L. Vietto, G. Nervo, Selection and testing of Populus alba and Salix spp. as bioenergy feedstock: preliminary results, Appl. Energy 102 (2013) 87-92.

[21] M. Manzone, G. Airoldi, P. Balsari, Energetic and economic evaluation of a poplar cultivation for the biomass production in Italy, Biomass Bioenergy 33 (9) (2009) 1258-1264.

[22] E. Barta-Rajnai, E. Jakab, Z. Barta, L. Wang, Ø. Skreiberg, M. Grønli, Comprehensive compositional study of torrefied wood and herbaceous materials by chemical analysis and thermoanalytical methods, Energy Fuels 30 (2016) 8019-8030.

[23] A. Friedl, E. Padouvas, H. Rotter, K. Varmuza, Prediction of heating values of biomass fuel from elemental composition, Anal. Chim. Acta 544 (2005) 191-198.

[24] I. Langmuir, The adsorption of gases on plane surfaces of glass, mica and platinum, J. Am. Chem. Soc. 40 (1918) 1361-1403.

[25] H.M.F. Freundlich, Über die adsorption in lösungen, Z. Phys. Chem. 57A (1906) 385-470.

[26] R. Sips, On the structure of a catalyst surface, J. Chem. Phys. 16 (5) (1948) 490-495.

[27] S. Lagergreen, Zur theorie der sogenannten adsorption gelöster stoffe kungliga svenska vetenskapsakademiens, Handlingar 24 (4) (1898) 1-39.

[28] Y.S. Ho, G. Mckay, Sorption of dye from aqueous solution by peat, Chem. Eng. J. 70 (2) (1998) 115-124.

[29] F. Wang, J. Zhao, H. Zhou, W. Li, N. Sui, H. Lui, O-carboxymethyl chitosan entrapped by silica: preparation and adsorption behavior toward neodymium(III) ions, J. Chem. Technol. Biotechnol. 88 (2013) 317-325.

[30] W. Ai, H. Duval, F. Pierre, P. Perré, Characterization of wood micromorphology from gas permeability measurements, Microfluid. Nanofluidics 21 (101) (2017) $1-15$.

[31] M.I. Ahmad, N.A. Bakri, Z.I. Rizman, M.S.M. Rasat, Z.A. Zainal-Alauddin, S.N. Mohamed-Soid, M.S. Abdul-Aziz, M. Mohamed, M.F. Mohd-amin, Morphology and bonding analysis of torrefied empty fruit bunch materials, Int. J. Adv. Appl. Sci. 4 (12) (2017) 302-308.

[32] M. Bartkowiak, R. Zakrzewski, Thermal degradation of lignins isolated from wood, J. Therm. Anal. Calorim. 77 (2004) 295-304

[33] S. Willför, A. Sundberg, A. Pranovich, B. Holmbom, Polysaccharides in some industrially important hardwood species, Wood Sci. Technol. 39 (8) (2005) 601-617.

[34] S. Li, C. Chen, M. Li, X. Xiao, Torrefaction of corncob to produce charcoal under 
[35] Y. Jiang, H. Chen, Q. Ge, J. Zhang, Efficient extraction and characterization of polymeric hemicelluloses from hybrid poplar, Carbohydr. Polym. 101 (2014) 1005-1012.

[36] G.F. Leal, L.A. Ramos, D.H. Barrett, A. Aprígio, S. Curvelo, C.B. Rodella, A thermo gravimetric analysis (TGA) method to determine the catalytic conversion of cellulose from carbon-supported hydrogenolysis process, Thermochim. Acta 616 (2015) 9-13.

[37] M.J.C. Van der Stelt, H. Gerhauser, J.H.A. Kiel, K.J. Ptasinski, Biomass upgrading by torrefaction for the production of biofuels: a review, Biomass Bioenergy 35 (9) (2011) 3748-3762.

[38] P. Sannigrahi, A.J. Ragauskas, Poplar as a feedstock for biofuels: a review of compositional characteristics, Biofuel Bioprod. Bior. 4 (2010) 209-226.

[39] H. Demey, M. Ruiz, J.A. Barron-Zambrano, A.M. Sastre, Boron removal from aqueous solutions using alginate gel beads in fixed-bed systems, J. Chem. Technol. Biotechnol. 89 (6) (2014) 934-940.

[40] A. Haug, Dissociation of alginic acid, Acta Chem. Scand. 15 (4) (1961) 950-952.

[41] S.K. Papageorgiou, F.K. Katsaros, E.P. Kouvelos, J.W. Nolan, H. Le, N.K. Kanellopoulos, Heavy metal sorption by calcium alginate beads from Laminaria digitata, J. Hazard. Mater. B 137 (2006) 1765-1772.

[42] M. Nasiruddin-Khan, A. Sarwar, Determination of points of zero charge of natural and treated adsorbents, Surf. Rev. Lett. 14 (3) (2007) 461-469.

[43] V.O. Vasylechko, G.V. Gryshchouk, V.P. Zakordonskiy, I.O. Patsay, N.V. Len, O.A. Vyviurska, Sorption of terbium on Transcarpathian clinoptilolite, Micropor. Mesopor. Mater. 167 (2013) 155-161.

[44] R. Isemin, S. Kuzmin, A. Mikhalev, O. Milovanov, D. Klimov, Torrefaction - the new method for decontamination of poultry litter (as biofuels or fertilizing), 17th Int. Multidiscip. Sci. GeoConference 17 (2017) 643-650.

[45] K. Attar, D. Bouazza, H. Miloudi, A. Tayeb, A. Boos, A.M. Sastre, H. Demey, Cadmium removal by a low-cost magadiite-based material: characterization and sorption applications, J. Environ. Chem. Eng. 6 (4) (2018) 5351-5360.

[46] S.A. El-korashy, K.Z. Elwakeel, A.A. El-hafeiz, Fabrication of bentonite/ thiourea-formaldehyde composite material for $\mathrm{Pb}$ (II), Mn (VII) and $\mathrm{Cr}$ (VI) sorption: a combined basic study and industrial application, J. Clean. Prod. 137 (2016) 40-50.

[47] T. Bohli, I. Villaescusa, A. Ouederni, Comparative study of bivalent cationic metals adsorption $\mathrm{Pb}(\mathrm{II}), \mathrm{Cd}(\mathrm{II}), \mathrm{Ni}(\mathrm{II})$ and $\mathrm{Cu}(\mathrm{II})$ on olive stones chemically activated carbon, Chem. Eng. Process Technol. 4 (4) (2013) 2-7.

[48] G.D. Klungness, R.H. Byrne, Comparative hydrolysis behavior of the rare earths and yttrium: the influence of temperature and ionic strength, Polyhedron 19 (2000) 99-107.

[49] R.G. Pearson, Hard and soft acids and bases, J. Am. Chem. Soc. 85 (22) (1963) 3533-3539.

[50] E. Nieboer, D.H.S. Richardson, The replacement of the non-descript term 'heavy metals' by a biologically and chemically significant classification of metal ions, Environ. Pollut. Ser. B 1 (1980) 3-26.
[51] H. Karami, Heavy metal removal from water by magnetite nanorods, Chem. Eng. J. 219 (2013) 209-216.

[52] K.G. Bhattacharyya, S. Sen-Gupta, Adsorptive accumulation of Cd (II), Co (II), Cu (II), $\mathrm{Pb}$ (II) and Ni (II) ions from water onto Kaolinite: influence of acid activation, Adsorpt. Sci. Technol. 27 (1) (2009) 47-68.

[53] T. Al-Masri, M.S. Amin, Y. Al-Akel, B. Al-Naama, Biosorption of cadmium, lead, and uranium by powder of poplar leaves and branches, Appl. Biochem. Biotechnol. 160 (2010) 976-987.

[54] R. Akkaya, Terbium adsorption onto polyhydroxyethylmethacrylate - hydroxyapatite composite and its modified composition by phytic acid, Desalin. Water Treat. 1-8 (2013).

[55] A. Miyazaki, R.M. Barnes, Complexation of some transition metals, rare earth elements, and thorium with a poly(dithiocarbamate) chelating resin recorder, Anal. Chem. 53 (2) (1981) 299-304

[56] C. Rill, Z.I. Kolar, G. Kickelbick, H.T. Wolterbek, J.A. Peters, Kinetics and thermodynamics of adsorption on Hydroxyapatite of the $\left[{ }^{160} \mathrm{~Tb}\right]$ terbium complexes of the bone-targeting ligands DOTP and BPPED, Langmuir 25 (4) (2009) 2294-2301.

[57] B.M.M. Saeed, A. Rusheed, Investigation of sorption of Tb(III) by 2-thenoyltrifluoroacetone supported onto polyurethane foam, Radiochim. Acta 90 (1) (2002) 35-42.

[58] T. Räsiänen, D. Athanassiadis, Basic chemical composition of the biomass components of pine, spruce and birch. Available online: http://www.biofuelregion.se/ UserFiles/file/ForestRefine/1_2_IS_2013-01-31_Basic_chemical_composition.pdf (accessed on 13th September, 2018).

[59] A. Samariha, M. Kiaei, Chemical composition properties of stem and branch in Alianthus altissima wood, Middel-East J. Scientific Res. 8 (5) (2011) 967-970.

[60] J.S. Tumuluru, S. Sokhansanj, J.R. Hess, C.T. Wright, R.D. Boardman, A review on biomass torrefaction process and product properties for energy applications, Ind. Biotechnol. 7 (5) (2011) 384-401.

[61] M. Ruiz, A.M. Sastre, E. Guibal, Palladium sorption on glutaraldehyde-crosslinked chitosan, React. Funct. Polym. 45 (3) (2000) 155-173.

[62] G.L. Rorrer, T.Y. Hsien, J.D. Way, Synthesis of porous-magnetic chitosan beads for removal of cadmium ions from waste water, Ind. Eng. Chem. Res. 32 (9) (1993) 2170-2178.

[63] A.M. Diez, M.A. Sanroman, M. Pazos, Fenton-based processes for the regeneration of catalytic adsorbents, Catal. Today 313 (2018) 122-127.

[64] A.A. Oladipo, M. Gazi, Hydroxyl-enhanced magnetic chitosan microbeads for boron adsorption: parameter optimization and selectivity in saline water, React. Funct. Polym. 109 (2016) 23-32. 